\section{Ankara Üniversitesi Eğitim Bilimleri Fakültesi Özel Eğitim Dergisi}

2022, 23(1), 219-241
DERLEME

Gönderim Tarihi: 18.06.20

Kabul Tarihi: 27.01.21

Erken Görünüm: 21.02.21

\title{
Özel Eğitimde Etik ve Etik Değerlendirmeler
}

\author{
Onur Özdemir iD 1
}

$\ddot{O} z$

Giriş: Meslek etiği; çalışanların mesleklerini icra ederken sergilemeleri ya da kaçınmaları gereken davranışları belirleyen, bildiren ve gözeten standartlar olarak ifade edilebilir. Etik ve uygulama ilkeleri, bu standartları somut biçimde tanımlamakta ve çalışanlara uygun mesleki davranışlara ilişkin kılavuzluk etmektedir. Bu nedenle etik ve uygulama ilkeleri, meslek etiğinin önemli bir parçasıdır. Çalışanlara, uygun mesleki davranışlar için yol gösteren bir diğer unsur ise etik değerlendirmelerdir. Etik değerlendirmeler, etik ihlallerde ya da ikilemlerde uygun kararlar vermeyi sağlayan sistematik problem çözme süreçleri olarak tanımlanmaktadır. Diğer alanlara kıyasla, özel eğitim alanının etik ihlallere ve ikilemlere karşı daha hassas bir konumda olduğu söylenebilir. Bu nedenle, eğitimcilerin etik ve uygulama ilkeleri ile etik değerlendirmeler hakkında bilgi ve becerilere sahip olmaları gerekmektedir. Bu gereksinimlere rağmen, Türkiye'de özel eğitim alanındaki meslek etiğine ilişkin çalışmaların yakın tarihte ortaya çıkmaya başladığı ve henüz sınırlı sayıda olduğu görülmektedir. Bu gereksinimler doğrultusunda, mevcut çalışmada öncelikle; etik ve meslek etiği kavramları ile özel eğitim alanındaki etik ilkelere ilişkin kuramsal bilgilerin sunulması, sonrasında da etik değerlendirmelere ilişkin bir uygulama örneğinin paylaşılması amaçlanmıştır.

Sonuç ve Öneriler: Mevcut çalışmada sunulan etik değerlendirme çerçevesi, özel gereksinimli öğrencilerle çalışanlar için faydalı olabilecek bir örnek sunmaktadır. Gelecek çalışmalar için Türkiye şartları gözetilerek geliştirilen çerçevelerin deneysel yöntemlerle değerlendirilmesi önerilmektedir. Bu ve benzeri çalışmalar, hem hizmet alanların hem de hizmet sağlayanların esenliğine katkı sağlayacaktır.

Anahtar sözcükler: Özel eğitim, meslek etiği, etik ilkeler, etik ikilemler, etik değerlendirme süreci.

Atıf için: Özdemir, O. (2022). Özel eğitimde etik ve etik değerlendirmeler. Ankara Üniversitesi Eğitim Bilimleri Fakültesi Özel Ĕ̈itim Dergisi, 23(1), 219-241. https://doi.org/10.21565/ozelegitimdergisi.754783

\footnotetext{
${ }^{1}$ Öğr. Gör. Dr., Marmara Üniversitesi, E-posta: onur.ozdemir@marmara.edu.tr, https://orcid.org/0000-0002-7242-6946
} 


\section{Giriş}

"Özel eğitim” teriminde yer alan özel kelimesi, alanda çalışan öğretmenlerin özel olarak yetiştirildiğini ve eğitim öğretim faaliyetlerinde kullanılan yöntemlerin özel olduğunu (Özel Eğitim Hizmetleri Yönetmeliği, 2018) vurgulamaktadır. Bununla beraber, "özel” terimi, alanın başka niteliklerini tanımlamak için de uygun bir kelimedir. Özel eğitim alanı, diğer branşların ulaşmakta zorlandığı öğrencilerin ve yakınlarının yaşam kalitelerini artırmaya yönelik çalışmaları içermektedir. Bu çalışmalar, profesyonel bir anlayışla yürütülse de öğretmen, öğrenci ve veli arasında özel bir yakınlık da barındırır. Kimi zaman bu etkileşimler; mesai saatleri ile sınırlı kalmayan, okuldaki etkinliklerin ötesine geçen ve karşılıklı saygıya dayalı bir yakınlık içerir. Bu gerçekleştiğinde ebeveynler, çocuklarının öğretmenlerini aileden biri gibi görürler (Nelson vd., 2004).

Üst paragrafta çizilen bu aydınlık tablo elbette pürüzsüz değildir, diğer tüm beşerî etkinlikler gibi özel eğitim alanı da çeşitli problemlere ve olumsuzluklara açıktır (Cook \& Schirmer, 2003). Bu problemlerin bazıları etiğe ilişkindir. Örneğin; öğrencilere uygun biçimde davranma, bütün öğrencilere eşit firsatlar sunma, öğrenciler için uygun programlar belirleme, velilerin görüşlerine saygı duyma ve kaynakların kullanımı konularında etik ihlaller ortaya çıkabilir (Howe \& Miramontes, 1991; Paul vd., 2002; Stephens, 1985). Kimi durumlarda da ortaya çıkan seçenekler arasından etik olanın belirlenmesinde güçlükler yaşanabilir. Sayılan bu gerekçelerden dolayı öğretmenlerin; davranışlarına ve bunların sonuçlarına ilişkin gelişmiş bir farkındalık içerisinde olmaları, buna göre hareket etmeleri gerekmektedir (Colnerud, 1997). Bu gereksinimlere rağmen, Türkiye'deki özel eğitim öğretmenlerinin bu yeterliklerle donatılmasına ilişkin çalışma ve tartışmaların ancak yakın zamanlarda ortaya çıkmaya başladığı görülmektedir. Öğretmen adaylarına yönelik "özel eğitimde etik" dersi 2016 yılında müfredata konmuş, özel eğitimciler için etik ilkelerin oluşturulmasına 2020 yılı itibari ile tamamlanmıştır. Türkiye'de özel eğitim meslek etiğine ilişkin yapılan çalışmaların sayısının ve kapsamının artması bir gerekliliktir. Bu çalışmayla özel eğitimcilerin, meslek etiğine ilişkin farkındalıklarına katkıda bulunulması amaçlanmaktadır. Bu maksatla, öncelikle etik kavramı, meslek etiği özelinde ve temel düzeyde ele alınmıştır. Sonrasında, Türkiye'deki ve Amerika Birleşik Devletleri’ndeki (ABD) bazı yasal ve örgütsel etik düzenlemeler değerlendirilmiştir. Yazının son kısmında ise etik ikilemlerde doğru kararlar vermede kullanılabilecek bir uygulama çerçevesi, Türkiye'de görülebilecek bir örnek olay bağlamında betimlenmiş̧tir.

\section{Etik ve Meslek Etiği}

Etik kelimesinin günümüzdeki yaygın kullanımı etik felsefesine dayanmaktadır. Etik felsefesi genel olarak doğru ve yanlış kavramlarıyla ilgilenen felsefe dalıdır ve farklı alt alanları kapsamaktadır. Örneğin metaetik, doğrunun doğasını anlamaya yöneliktir: "Doğru-yanlış nedir? Bir şeyin doğru ya da yanlış olduğunu nasıl söyleyebiliriz?" gibi sorular ve bunların yanıtları meta-etik kapsamında ele alınmaktadır. Psikoloji, sosyoloji ve antropoloji alanlarındaki çalışmalarla beslenen betimleyici etik ise insanların herhangi bir durumdaki (doğru) etik ve etik dışı (yanlış) davranışları ile ilgilenmektedir. Buna göre; "İnsanlar ve toplumlar hangi durumlarda nasıl davranırlar?" sorusu, betimleyici etiğin ele aldığı bir sorudur. Alt disiplinlerden bir diğeri olan normatif etik ise, ideal davranışlarla ilgilenmektedir. "İnsanlar nasıl davranmalıdır?" sorusu temel alınarak, yapılması doğru ve yanlış olanlar tartışılmaktadır. Son olarak uygulamalı etik; normatif etiğin ele aldığı tartışmaların belirli bir durum özelinde değerlendirilmesini içermektedir (O’Donohue \& Ferguson, 2011; Uzun \& Yolsal, 2008). Etik kelimesi; günlük yaşamda daha çok, normatif ve uygulamalı etik kapsamında, yani ideal davranışların ne olması gerektiğini tanımlayan anlamıyla karşımıza çıkmaktadır. Bu kullanımlara uygun bir tanımlamaya göre etik; "bireysel ve toplumsal düzeylerde işlerin nasıl yapılması gerektiğini belirlemede yardımcı olan kılavuz değerler, ilkeler ve standartlardır" (Uzun \& Yolsal, 2008). Bu değerler, ilkeler ve standartlar belirli bir topluluğa (ör. kanarya sevenler derneği üyelerine) doğru ve yanlış davranışları tanımlamaktadır. Tanımlanan bu doğrular ve yanlışlar, topluluğun bir araya gelme amaçlarına ilişkindir. Buna göre örneğin, kanarya sevenler derneği etik ilkelerinde kanaryaların istismar edilmemesi gerektiğine ilişkin kuralların olması, öğretmen davranışlarına ilişkin kuralların ise olmaması beklenir. Eğer söz konusu topluluk meslek üyelerinden oluşuyorsa, söz konusu ilkeler meslek etiği olarak isimlendirilmektedir. Meslek etiği "mesleki davranışları değerlendiren, uygun ve uygun olmayan davranışları belirten ilkeler ve standartlar" biçiminde tanımlanmaktadır (İşgüden \& Çabuk, 2006). Downie’ye (1980) göre; farklı mesleklere ilişkin etik ilkeler, farklı içerikler barındırsa da genel olarak şu üç ortak temayı içermektedir: Meslek üyelerinin (a) mesleki yeterliliklerine ilişkin ilkeler, (b) mesleki bütünlüklerine ilişkin ilkeler ve (c) mesleki yöntemlerine ilişkin ilkeler. İlgili meslek dalında, bu temalar etrafında oluşturulan etik ilkeler; çalışanlara ideal mesleki davranışlara ilişkin kılavuzluk etmektedir.

Doğru ve yanlış davranışlarla ilişkili bir başka kavram da ahlaktır. Ahlak, insanların başkalarını etkileyen davranışlarını kontrol etmeye yönelik gayri resmî toplumsal bir sistem olarak tanımlanmaktadır. Bu sistem, içerdiği ve gözettiği birtakım kurallar vasıtasıyla kişiyi toplumsal doğrulara yönlendirmeye çalışmaktadır (Audi, 
1999). Etik ve ahlak kavramları bazen birbirlerinin yerine de kullanılmaktadır, örneğin Türkçede iş ahlakı ve meslek ahlakı kavramları ile karşılaşılmaktadır. Ancak etik kavramı günümüzde daha çok, yukarıdaki paragrafta da belirtildiği üzere, belirli bir topluluğun üyelerinin sergilemesi gereken davranışlar için kullanılmaktadır. Bu iki kavram arasındaki ayrışmanın kaynağına ilişkin bir açıklama Durkheim'dan (1957) gelmektedir. Durkheim (1957), modern toplumların ortaya çıkmasıyla beraber, toplumsal yargıların bireylerin mesleki davranışlarını değerlendirmede geçerliliğini yitirdiğini söylemektedir. Toplumsal iş bölümü nedeniyle, herhangi bir mesleğin gerektirdiği ve uzmanlık içeren davranış biçimlerine ilişkin toplumsal anlayış sınırlı hale gelmiştir. Bu nedenle genel toplumsal ahlak, artık mesleki davranışlara ilişkin kanaat bildirmemektedir. Bu görev meslek örgütlerince, meslek etiği vasıtasıyla yerine getirilmektedir. Bu ayrışma neticesinde, ahlaki yargılar genelde kişinin meslek hayatı dışındaki davranışları, etik yargılar ise mesleki davranışları için kullanılagelir olmuştur. Bu iki kavramın farklılıklarına ilişkin bir başka açıklama ise doğru ve yanlış kararındaki bakış açılarına ilişkindir. Gert ve Gert'e (2017) göre ahlaki yargılar daha çok kişisel bakış açısı ile şekillenmektedir. Ahlak toplumsal bir sistem olarak kendi doğrularını bireye dikte etse de bunların tam bir tahakkümü yoktur. Birey, toplumun dikte ettiği ahlak anlayışını kendi değerlerini de katarak içselleştirir ve kendi ahlaki yargı sistemini oluşturur (Frolov, 1997). Diğer yandan; yukarıda belirtilen tanım hatırlatılacak olursa, meslek etiğinin dikte ettiği doğru ve yanlış davranışlar kişisel bakış açısına müsaade etmemektedir. Böylece, söz konusu gruplar ya da örgütlerce oluşturulan harici standartlar aracılığıyla üyelerin kişisel özelliklerinin ve öznel bakış açısının etkisi azaltılmaktadır (Weaver, 2007). Buna göre örneğin, bir öğretmen kendi ahlaki yargılarını öznel ifadeler ile belirtebilir (ör. "bence evlenmeden çocuk sahibi olmak ahlaken yanlıştır). Ancak meslek etiğinde belirtilmiş davranışlar için kişisel yargılarda (ör. "bence öğretmenler sınıfındaki öğrencilere özel ders verebilir.”) bulunamaz. Çünkü öğretmenlerin "kanuni istisnalar hariç olmak üzere öğrencilere ücret veya başka bir menfaat karşılığı özel ders vermeyecekleri” mesleki etik ilke olarak öğretmenlere bildirilmiştir (Milli Eğitim Bakanlığı [MEB], 2015).

Doğru ve yanlış davranışları tanımlayan, kurallara bağlayan bir diğer sosyal yapı da hukuktur. Hukuk, toplumu düzenleyen yasalar bütünü olarak tanımlanmaktadır. Yasa ise "devletin yasama organları tarafindan konulan ve uyulması gereken kurallar bütünüdür” (Türk Dil Kurumu, t.y.). Yasalar ve diğer hukuk normları da (ör. tüzük, yönetmelik, vb.) yapılması ve yapılmaması gerekenleri bildirir (Kuluçlu, 2008). Yasalara uymak da genelde iyi ve dürüst bir insan davranışı olarak görülür (Collins, t.y.). Ancak hukuk ve etik, yapılması ve yapılmaması gerekenlere ilişkin olarak her zaman ortak yargılar barındırmazlar. Bazı durumlarda hukuk kuralları etik kabul edilmeyen birtakım hükümleri kapsayabilir ve bu durumda bireyler hukuk kurallarına uymayarak ya da itiraz ederek doğru (etik) davranış sergilemiş olurlar. Örneğin ABD'de 1970'li yıllar itibariyle özel gereksinimli öğrencilerin, normal gelişim gösteren akranları ile beraber eğitim görmelerini güvence altına alan genel bir hukuksal bir düzenleme yoktu. Okul idareleri, bazen de keyfi biçimde uygun gördükleri öğrencileri normal eğitim sınıflarına kabul ediyor, uygun görmediklerini ise özel eğitim okullarına ya da sınıflarına yönlendiriyordu (Osgood, 2005). Hukuka uygun olan, ancak etik olmayan bu ve benzeri uygulamalar, ancak bireylerin ve sivil toplum örgütlerinin verdikleri mücadeleler sonucunda kaldırılabilmiş (ör. 1972 yılında karara bağlanan Mills ve Kolombiya Bölgesi Eğitim Kurulu Davası [Justia US Law]) ve sonunda yasa dışı hale gelmiştir (Weiss \& Mettrick, 2010). Bu örnek, yasaların bireyleri her zaman etik davranışa yönlendirmediğini; ancak toplumsal dinamiklerin de etkisiyle yasaların zaman içerisinde etik olarak doğru olana evrilebileceğini göstermektedir. Etik ve hukuk arasındaki diğer bir önemli farklılık da hukuki mevzuatın kapsam sınırından dolayı ortaya çıkmaktadır. Hukuki normlar; sorumlulukları, hakları ve işleyişi betimler ancak bunlar genellikle doğaları gereği bağlamı dikkate almazlar (Bon \& Bigbee, 2011). Örneğin Özel Eğitim Hizmetleri Yönetmeliği (2018) bütün kaynaştırma öğrencileri için bireyselleştirilmiş eğitim programı (BEP) hazırlanmasını şart koşar. Ancak BEP'i uygulayan öğretmenin, kaynaştırma öğrencisini her zaman sınıfın en arkasına oturtmasına karşı bir hüküm barındırmaz. Yasal mevzuattaki boşlukların, bir başka deyişle gri alanların, neden olduğu sınırlıkların üstesinden gelebilmek için, mesleki etik ilkelere başvurulması (Kamu Görevlileri Etik Kurulu, 2012) ve/veya etik değerlendirmeler yapılması gerekmektedir. Örneğin; öğrencisine sınıfta firsat eşitliği sağlamayan bir öğretmenin davranışı, çalıştığı kurumun etik kurulunca değerlendirilebilir ve bu öğretmen meslek etiği ilkeleri gereği yaptırıma uğrayabilir.

Yasal mevzuatı tamamlayan meslek etiği uygulamaları ile son yıllarda gitgide daha fazla karşılaşılmaktadır. Türkiye'de 2000'li yıllar itibariyle, kamuda ve özel sektörde etik uygulamaları gözeten ve kollayan kurumların sayısı artmaya başlamıştır. Örneğin Kamu Görevlileri Etik Kurulu, kamu görevlilerinin uymaları gereken etik davranışları belirlemek ve gözetmek amacıyla 2004'te kurulmuştur. 2005 yılında yayımlanan "Kamu Görevlileri Etik Davranış İlkeleri ile Başvuru Usul ve Esasları Hakkında Yönetmelik" ile kamu görevlileri için genel etik ilkeler ortaya konmuştur (Kamu Görevlileri Etik Kurulu, 2012). Sonraki y1llarda da çeşitli kamu kurumları personellerinin (ör. Gümrük personeli, Sayıştay denetçileri) uymaları gereken etik kurallar yasal mevzuata dâhil edilmiştir. Bunun yanı sıra çeşitli meslek örgütleri ve odaları (ör. Türk Psikologlar Derneği, Harita ve Kadastro Mühendisleri Odası) kendi üyeleri için belirlenmiş olan etik ilkeleri yayımlamıştır. 
$\mathrm{Bu}$ dönemlerde iş dünyasındaki etik uygulamaları yaygınlaştırmak ve takip etmek amacıyla kurulan çeşitli etik dernekleri de (ör. Etik ve İtibar Derneği, Toplumsal Etik Derneği) çalışmalarına devam etmektedir. Çalışanların davranışlarını düzenlemelerine yardımcı olan ve belli bir yaptırım gücüne sahip etik kurallar, Türkiye'de mesleki uzmanlığın önemli öğelerinden biri haline gelmiştir. Meslek etiğine ilişkin bu gelişmeler, öğretmenlik mesleğine de yansımaktadır. Son yıllarda eğitim öğretim faaliyetlerinde, etik ve etik dışı davranışlara ilişkin çalışmalar artmaktadir.

\section{Eğitimde ve Özel Eğitimde Etik}

Hodgkinson'a (1991) göre, eğitim-öğretim faaliyetleri temel birtakım değerlere bağlı etik ve ahlaki etkinliklerden ibarettir. Bu bağlamda etik davranışlar, öğretmenlik mesleğinin özünde yer almaktadır (Bullough, 2011; Keser vd., 2013). Okulların görevi; bireyi yaşama adapte etmek, sağlıklı bir karakter ve haysiyet oluşumunu desteklemek olarak tanımlandığında da öğretmenlik mesleğini içeren davranışlar, etik sorumluluklardan ayrı düşünülemez hale gelmektedir (Fenstermacher, 1990). Öğretmenlerin bu sorumluluğu üstlenmeleri için gerekli olan temel şartlardan bir tanesi mesleki etik ilkelerin oluşturulması ve bunların gözetilmesidir. Mesleki etik ilkeler sayesinde uygun ve uygun olmayan öğretmen davranışlarının sınırları çizilmektedir. Mesleki etik ilkelerin ortaya konması ile kişisel fikirler ya da tercihler yerine, uygun davranışlara ilişkin temel standartlar getirilmiş olmaktadır (Warnick \& Silverman, 2011). Etik ilkeler; öğretmenlerin davranışlarının sonuçları, uzmanlıklarının amaçları ve sınırları ile uygun davranışlar hakkında anlayış kazanmalarını da sağlamaktadır (Apgar, 2018). Bazı ülkelerde eğitimci davranışlarını düzenleyen etik ilkelerin yüz yıla yaklaşan bir tarihi olduğu görülmektedir. Örneğin ABD'de mesleki örgütlerden biri olan "Ulusal Eğitim Birliği”" (The National Education Association) üyelerinin uyması gereken etik kodları (ilkeleri), 1929 yılında yayımlamıştır. Bu belgede etik kodlar; (a) öğrenciler ve toplum ile ilişkilere dair etik kurallar, (b) öğretmenlik mesleğine ilişkin etik kurallar ve (c) diğer meslek üyelerine ilişkin etik kurallar başlıkları altında toplam 21 madde olarak belirtilmiştir. Türkiye'de ise eğitimcilere etik ilkelere ilişkin doğrudan talimat veren ilk belge, MEB tarafından 2015 yılında yayımlanmıştır. "Eğitim-Öğretim Hizmeti Verenler için Mesleki Etik İlkeler” ismini taşıyan belgenin yer aldığı genelgede, etik ilkelerin okullardaki bütün personele duyurulması istenmiştir. Tablo 1'de "Eğitim-Öğretim Hizmeti Verenler için Mesleki Etik İlkeler" belgesinde yer alan başlıklar yer almaktadır (MEB, 2015).

Herhangi bir mesleğe ilişkin etik kuralların; genel geçer ilkelerle ve kültürün-zamanın gereksinimlerine yanıt veren değerlendirmelerden oluştuğu söylenebilir. Öğretmenlik mesleği etik kuralları için de bu geçerlidir. $\mathrm{Bu}$ durumun örnekleri yukarıdaki belgelerde de görülmektedir. Örneğin; "Eğitim-Öğretim Hizmeti Verenler için Mesleki Etik İlkeler"in ilk maddesi olan "Sevgi ve Saygı" maddesi başlığında; "Küçüklere karşı sevginin, büyüklere karşı saygının önemini anlatırken öncelikle kendisi örnek olur” denilmektedir. Bu ifade şüphesiz, Türkiye'de her kesimden bireyin aşina olduğu ve buna uygun davranılmasının beklendiği ortak kültürel bir değeri yansıtmaktadır. On dördüncü maddede ise, öğretmenlerin öğrencilerine özel ders veremeyeceği belirtilmektedir. Bu kuralın varlığını ülkemizdeki öğretmenlerde özel ders verme davranışının görülüyor olması ve bunun önüne geçilmek istenmesi ile açıklamak mümkündür. İlginç bir biçimde; özel ders verme davranışına ilişkin doğrudan bir madde, ABD'deki Ulusal Eğitim Birliğinin 1929 yılında yayımladığı etik ilkeler içerisinde de yer almaktadır. Buna göre, farklı coğrafyalarda ve farklı zaman dilimlerinde aynı ilkeye gereksinim duyulmuş olduğu söylenebilir. Ulusal Eğitim Birliği son yayımladığı etik ilkelerde bu maddeye gereksinim duymamıştır (The National Education Association, 2010). 1929 yılındaki belgede yer alan kurallardan bir diğeri; öğretmenin, mevcut kurumunu ücret artışı konusunda zorlamak adına başka bir kuruma başvurmasını yasaklamaktadır. Özel ders vermeye ilişkin maddede olduğu gibi, Ulusal Eğitim Birliğinin güncel etik kodlarında böyle bir madde yer almamaktadır. Bu değişiklik, ABD'deki iş ve işveren haklarında, sendikalaşma ve toplu sözleşme olanaklarındaki gelişmelerin etkisi bağlamında ele alınabilir (Bascia, 2015).

\section{Tablo 1}

Ĕgitim-Öğretim Hizmeti Verenler İçin Mesleki Etik Illkeler

1. Öğrencilerle ilişkilere dair etik ilkeler
a. Sevgi ve saygı
b. İyi örnek olma
c. Anlayışlı ve hoşgörülü olma
d. Adil ve eşit davranma
e. Öğrencinin gelişimini gözetme
f. Öğrenciye ait bilgileri saklama
g. Menfi psikolojik durumları yansıtmama
h. Kötü muameleden kaçınma


Tablo 1 (devami)

2. Eğitim mesleğine ilişkin etik ilkeler

a. Mesleki yeterlilik

b. Sağlıklı ve güvenli eğitim ortamı sağlama

c. Mesai ve ders saatlerine uyma

d. Hediye alma

e. Kişisel menfaat sağlama

f. Özel ders verme

g. Bağış ve yardım talebinde bulunma

3. Eğitimcilerle ilișkilere dair etik ilkeler

"Meslektaşları arasında ırk, dil, din, renk, cinsiyet, siyasi görüş ve aile statüsüne dayalı ayrımcılık yapmaz..."

4. Velilerle ilişkilere dair etik ilkeler

"Çocuklarıyla gerektiği gibi ilgilenmeleri konusunda velileri yönlendirir. Veliler arasında ırk, dil, din, renk, cinsiyet, siyasi görüş ve aile statüsüne dayalı ayrımcılık yapmaz."

5. Okul yönetimi ve toplumla ilişkilere dair etik ilkeler

"Öğrencilerin kaliteli bir eğitim-öğretim hizmeti almasını sağlamak için okul yönetimi ile işbirliği yapar, süreçte karşılaştığı sorunları yetkili birime bildirir..."

6. Okul yöneticilerinin; öğretmenler, öğrenciler ve velilerle ilişkilerine dair etik ilkeler "Okul yöneticileri; eğitim ve öğretimin sağlıklı ve güvenli bir ortamda yapılabilmesi için gereken önlemleri alır..."

Not: Uyarlandığı kaynak “Eğitimciler İçin Mesleki Etik İlkeler Genelgesi, Milli Eğitim Bakanlığı, 2015.”

Özel eğitim alanına gelindiğinde, ilk dönemlerden itibaren doğru olanı yanlıştan ayırmaya ilişkin çeşitli çabalar ile karşılaşılmaktadır. Tarih içinde yüzyıllar boyunca, özellikle batı medeniyetlerinde özel gereksinimli bireyler olumsuz tutumlara maruz kalmış, nadiren eğitim hakkına kavuşmuşlardır. Bu bireylerin düzeyleri ne olursa olsun, genel eğitim hizmetlerine ulaşma hakkının tanınması ve gözetilmesinin etik bir sorumluluk olduğunun fark edilmesi için, insanlık tarihinde uzun bir sürenin geçmesi gerekmiştir (Howe \& Miramontes, 1991). Özel gereksinimli bireylerin kurumsal düzeyde eğitim olanaklarına kavuşmaları, 18. yüzyılın ortalarında ortaya çıkan aydınlanma çağının getirdiği akılcı yaklaşımlar ve eşitliğe dayalı sosyal hareketler ile mümkün olabilmiştir (Winzer, 1993). Bu bağlamda; özel eğitim hizmetleri bir bakıma, etik olmayan bir durumu (özel gereksinimli bireylere eğitim verilmemesi) düzeltmeye ilişkin yaklaşımların ve çabaların bir ürünü olarak da ele alınabilir (Paul vd., 2002). Temellerindeki bu insancıl anlayışa ve günümüze dek devam eden gelişmelere rağmen özel eğitim alanında etik ihlaller ile hala karşılaşılmaktadır. Etik ihlaller çok farklı biçimlerde ortaya çıkabilmektedir. Türkiye'de yapılan bir çalışmada Akçamete ve diğerleri (2016, s. 41), özel eğitim alanında çalışan öğretmenlerin karşılaştıkları şu etik dışı davranışları rapor etmişlerdir: "Mesleki eğitim almayanların ve mesleki eğitimi yetersiz olanların hizmet vermesi, maddi çıkar sağlamanın birinci planda olması, öğrencilere firsat eşitliği sunulmaması, ailenin beklentilerinin ve ihtiyaçlarının göz önünde bulundurulmaması, aileye yanlış bilgi verilmesi, ailenin bilinçsizliğini ve duygularını istismar etme, aileye saygı duymama.” Görüldüğü üzere; özel eğitimde etik dışı davranışlar medyada dikkat çeken, "öğrenciye şiddet uygulanması" ya da "kaynaştırma öğrencisine diğer velilerin tepki göstermesi” gibi örneklerden çok daha farklı biçimlerde de ortaya çıkabilmektedir. Önceki bölümde de belirtildiği üzere, yayımlanan mesleki etik ilkeler ile bu ve diğer etik dışı davranışların önüne geçilmeye çalışılmaktadır. Bunlardan bir tanesi ABD'de yer alan Ayrıcalıklı Çocuklar Konseyinin (Council for Exceptional Children [CEC]) 2015 yılında yayımladığı, Etik İlkeler ve Mesleki Uygulama Standartları'dır. Tablo 2'deki maddelere bakıldığında; bunların Akçamete ve diğerlerinin (2016) belirttiği etik dışı davranışlarla benzerlik gösterdiği görülmektedir. Türkiye'de özel eğitimciler için uygun davranışlara atıf yapan en yakın kaynak olan Özel Eğitim Alanı Özel Alan Yeterlikleri belgesi (MEB, 2008), 2018'de yürürlükten kaldırılmıştır. Yürürlükte olan resmi mevzuatlara bakıldığında; 1997'de yayımlanan 573 sayılı Özel Eğitim Hakkında Kanun Hükmünde Kararname'deki dördüncü madde, "özel eğitimin temel ilkelerine” yer vermektedir. Bu ilkeler, özel eğitim uygulamalarındaki temel noktalara işaret etmektedir. Bu nedenle ülkemizde özel eğitimde etiğe ilişkin en yakın yasal kaynak sayılabilir. Türkiye'de özel eğitimciler için etik standartlar yakın bir zamanda oluşturulmuştur. Özel eğitim alanındaki akademisyenlerin, öğretmenlerin ve sivil toplum örgütlerinin bir araya gelerek oluşturduğu bir kurul, özel eğitim öğretmenleri için etik ilkelerinin belirlenmesine yönelik çalışmalarını 2020 yılında tamamlamıştır (Vuran, 2020). Bu kılavuzun yayımlanması ile önemli bir eksiklik giderilmiştir. 
Tablo 2

Etik Illkeler ve Mesleki Uygulama Standartlart

1. Özel gereksinimli bireylerin itibarı, kültürü, dil ve geçmişlerine saygı gösterecek şekilde, mümkün olan en yüksek öğrenme çıktısını sağlamaya ve yaşam kalitelerini geliştirmeye ilişkin beklentiler oluşturmak ve sürdürmek

2. Yüksek seviyede mesleki yetkinlik ve bütünlük sağlamak, özel gereksinimli bireylere ve ailelerine fayda sağlayan mesleki değerlendirmeler yapmak

3. Özel gereksinimli bireylerin okullarında ve topluluklarında anlamlı ve kapsayıcı katılımlarını teşvik etmek

4. Özel gereksinimli bireylere hizmet sağlayan kişilerle iş birliği yapmak

5. Ailelerle karşılıklı saygıya dayalı ilişkiler geliştirmek, aileleri ve özel gereksinimli bireyleri eğitsel karar alma sürecine dâhil etmek

6. Uygulamalarda; kanıtları, eğitim-öğretim verilerini, araştırma ve mesleki bilgileri kullanmak

7. Özel gereksinimli bireylerin fiziksel ve psikolojik güvenliklerini korumak ve desteklemek

8. Özel gereksinimli bireylere zarar verecek herhangi bir uygulamada bulunmamak ve böyle bir duruma müsamaha göstermemek

9. Mesleki etik, standartlar ve Ayrıcalıklı Çocuklar Konseyinin politikaları doğrultusunda uygulama yapmak, mesleki uygulamayı etkileyen yasaları, düzenlemeleri, politikaları korumak ve yasalar, düzenlemeler, politikalardaki gelişimi ve iyileştirmeleri savunmak

10. Özel gereksinimli bireylerin öğrenme çıktılarını geliştirecek mesleki koşulları ve kaynakları desteklemek

11. Mesleki topluluklara aktif katılım yoluyla mesleğin gelişimi için çalışmak

12. Mesleki bilgi ve becerilerin gelişmesine ve yaygınlaşmasına katkı sağlamak

Not: Uyarlandığı kaynak "Ethical Principles and Professional Practice Standards for Special Educators, Council for Exceptional Children, 2015."

\section{Özel Eğitimde Etik Değerlendirmeler}

Türkiye'de özel eğitime ilişkin etik ilkelerin oluşturulması ve uygulanması, alan için çok önemli bir gelişmeye işaret etmektedir. Bu sayede öğretmenlerin etik konulara ilişkin farkındalıklarının artması ve davranışlarında bu ilkelerin gözetmeleri beklenebilir. Ancak etik ilkelerin varlı̆̆ı, doğru mesleki davranışların sergilenmesi için her zaman yeterli olmayabilir. Bazı durumlarda, önceden belirlenmiş olan etik ilkeler, karşılaşılan etik ikilemler karşısında yetersiz kalabilir. Bu nedenle, öğretmenlerin, davranışlarının etik bakımdan uygunluğunu bağımsız biçimde değerlendirebilecek yeterlikte olmaları da gerekmektedir (Warnick \& Silverman, 2011). Etik değerlendirmeler, belirli durumlarda hangi davranışların uygun, hangilerinin uygun olmadığı ile ilgilenir ve "Her şeyi göz önüne alarak, belirli bir durum karşısında, ne yapmak gerekir?" sorusuna cevap vermeyi amaçlar (Benjamin \& Curtis, 1981). Eğitimciler için bu sorunun yanıtı aslında açıktır; "çocuğun/öğrencinin üstün yararı" neyi gerektiriyorsa onu yapmak gerekmektedir (Stefkovich \& O’Brien, 2004). Ancak bazı durumlarda, hangi seçeneğin çocuğun/öğrencinin üstün yararına olduğu çok belirgin olmayabilir. Farklı sonuçlar doğurabilecek birden fazla davranış seçeneğinin ortaya çıktığı ve bu seçeneklerin birbirlerine karşı açık bir üstünlüğünün görülmediği durumlara etik ikilemler denilmektedir (Paul vd., 2002). Pek çok farklı değişkenin varlığında, etik ikilemlerde doğru sonuca ulaşmak her zaman kolay olmayabilir. Bireysel özellikler, mesleki etik ilkelerin varlığı ya da yokluğu, kurum kültürü, kamuoyu ilgisi ya da ilgisizliği, ekonomik bağlam, yasal mevzuat, ilgili politikalar, toplumsal ya da kültürel öğeler, çevresel özellikler, sosyal-idari baskılar verilecek kararlarda olumlu veya olumsuz etkiler gösterebilmektedir (Ehrich vd., 2011; Friedman, 2017; Prentice, 2014).

Öğretmenlerin etik ikilemlerde doğru kararlar vermeleri ya da etik problemleri doğru analiz edebilmeleri için etik karar verme yöntemleri/çerçeveleri hakkında bilgi sahibi olmaları gerekmektedir. Alanyazında, etik değerlendirmeleri yapılandırılmış bir çerçevede sunan çeşitli çalışmalar yer almaktadır (ör. Benninga, 2013; Stockall \& Dennis, 2015; Warnick \& Silverman, 2011). Bunlar; yöntem ya da çerçeve biçiminde tanımlanmakta, genel olarak etik ikilemleri çözülmesi gereken bir problem gibi ele almakta ve problem çözme basamaklarının sırayla uygulanmasını içermektedir. Metnin bu kısmında; etik değerlendirmelere ilişkin çerçevelerden bir tanesi (Warnick \& Silverman, 2011) Türkiye'de yaşanabilecek örnek bir olay üzerinden ele alnacaktır. Warnick ve Silverman (2011), karar basamağında somut bir metot sunmadıkları için, çalışmalarını yöntem olarak değil de uygulama çerçevesi olarak tanımlamaktadırlar. Uygulamalarının çıkış noktası, öğretmen adaylarına etik karar verme sürecinde yardımcı olacak bir çerçeve yapı sunmaktır. Uygulama birbirini takip eden dokuz basamaktan oluşmaktadır. Bu basamaklar Tablo 3 'te yer almaktadır.

\section{Tablo 3}

Etik Değerlendirme İçin Basamaklar 
Tablo 3 (devami)

4. Karara ilişkin seçeneklerin belirlenmesi

5. Seçeneklerin etik analizinin yapılması

a. Sonuca dayalı analiz

b. Etik analiz

6. Durumun öğretmen gözüyle değerlendirilmesi

7. İkileme ilişkin görüş alışverişi ve araştırma yapılması

8. Bir karar verilmesi, kararın diğer seçenekler arasından neden seçildiğinin gerekçelendirilmesi

9. Karar verildikten sonraki sürecin nasıl takip edileceğinin belirlenmesi

Not: Uyarlandığı kaynak "A Framework for Professional Ethics Courses in Teacher Education, B. R. Warnick \& S. K. Silverman, 2011, Journal of Teacher Education, 62(3), s. 278.” Telif Hakk1, 2011 Sage Publishing'e aittir.

Warnick ve Silverman (2011), bu basamakların her birini başka meslek dalları için oluşturulmuş olan karar verme modelleri ve alanyazındaki tartışmalar ile temellendirmiştir. Bu uygulama çerçevesi, özellikle özel eğitim alanı için oluşturulmuş değildir. Ancak içerdiği basamaklar genel ilkeleri tarif ettiği için, özel eğitim alanındaki durumlara da kolaylıkla uyarlanabilmektedir. Bu yaklaşımların önemli bir avantajı da bunları uygulayan öğretmenlere, etik ikilemler daha gündeme gelmeden, proaktif davranış becerilerini kazandırmasıdır (Stockall \& Dennis, 2015). Eğitim kurumlarında personellere bu yöntemlere ilişskin eğitimler sunulduğunda ve uygulamalar takip edildiğinde, kurumda etik kültürün oluşması ve gelişmesi mümkün olmaktadır (Brodhead \& Higbee 2012). Aşağıda bir örnek olay eşliğinde Warnick ve Silverman (2011) tarafindan önerilen basamaklar açıklanmaktadır. Örnek olayda; özel gereksinimli bir öğrenci için eğitsel değerlendirme sürecinin başlatılmaması ve okuldaki bazı yapısal sorunlar ile ilişkili bir etik ikilem sunulmaktadır. Ayrıca Warnick ve Silverman'ın (2011) oluşturduğu dokuz basamaklı çerçeveyi Okul Müdürü Ali Bey’in karşılaştığı ikilemi çözmek için nasıl kullanabileceği aşağıda açıklanmaktadır.

\section{Örnek Olay}

25 yıllık deneyimli bir öğretmen olan Ayşe Hanım, okulların açılmasına 15 gün kala kendisini oldukça kaygılı hissetmektedir. Hissettiği bu kaygı, Ayşe öğretmenin sahip olduğu yüksek mesleki sorumluluklar ile ilişkilidir. Göreve yeni başlayan okul müdürü, Ayşe öğretmene telefonda, tanı almamış ama yüksek ihtimalle zihin yetersizliği olan bir ikinci sınıf öğrencisini sınıfına kabul edip etmeyeceğini sormuştur. Öğrenci halen aynı okulda başka bir şubede kayıtlıdır. Öğrencinin babası Zeki Bey, yeni eğitim yılında çocuğunu Ayşe öğretmenin sınıfına yazdırmak istemektedir. Ahmet isimli öğrenci aslında yedi yaşına kadar yaşıtlarından daha yavaş bir gelişim göstermiştir, ancak geçen sene okula başlayınca gelişim farklılığı daha fazla dikkat çekmeye başlamıştır. Birinci sınıfta, özellikle Türkçe ve matematik derslerindeki kazanımları çok sınırlı olmuştur. Durumu fark eden birinci sınıf öğretmeni, rehberlik servisini ve öğrencinin velisini bilgilendirmiştir. Ancak çocuğunun tanı almasını istemeyen Zeki Bey, konuyla ilgili herhangi bir adım atmamıştır. Velinin isteksizliği nedeniyle, geçen seneki okul müdürü de öğrencinin eğitsel değerlendirme isteği formunu, rehberlik araştırma merkezine göndermemiştir. Sınıf öğretmeni de birkaç hafta daha öğrenciyle ilgilenmiş ancak öğrencide bir gelişme görmeyince çocuğu sınıfta kendi haline bırakmıştır. Öğrencinin okuldaki bir eğitim-öğretim yılı böylece geçmiştir.

Yeni eğitim-öğretim yılı başında, Zeki Bey daha önceden ahbaplığı olan Ali Bey okula müdür olunca, ondan yardım istemiştir. Ali Bey’den çocuğunu daha önceden methini duyduğu Ayşe öğretmenin şubesine geçirmesini istemektedir. Bu sayede çocuğunun herhangi bir eğitsel tanı almadan diğer öğrencilere yetişeceğini ummaktadır. Müdür Ali Bey, öğrenci için kaynaştırmanın daha iyi olacağını söylemiş ancak Zeki Bey’i ikna edememiştir. Zeki Bey, diğer çocukların ve velilerin kaynaştırma öğrencilerine iyi gözle bakmadıklarını bildiğini söylemiş, ricası yerine getirilmezse de öğrenciyi başka bir okula yazdıracağını ima etmiştir. Arkadaşını kırmak istemeyen Müdür Ali Bey, biraz vakit kazanmak için Ayşe öğretmen ile konuşup kendisine cevap vereceğini söylemiștir.

$\mathrm{Bu}$ sene ikinci sınıf öğrencilerini okutacak olan Ayşe öğretmenin sınıfında hali hazırda iki kaynaştırma öğrencisi vardır. Bu öğrenciler geçen sene Ayşe öğretmenin çabaları ile ilk defa tanı almış, hafif düzeyde zihinsel yetersizlik gösteren öğrencilerdir. Öğrenciler tanı alıp kaynaştırma öğrencisi olarak sınıflarına devam edince, özel eğitim öğretmenliği okuyan kızının da yardımları ile Ayşe öğretmen, bu öğrencileri için uyarlama çalışmalarına başlamıştır. Gösterdiği bu çabalar da sonuçsuz kalmamış, öğrenciler yaşıtlarına benzer kazanımlar elde etmişlerdir. Ancak geçen seneden beri okulundan anlamlı bir destek görmemesi Ayşe öğretmeni çok yormuştur. $\mathrm{Bu}$ iş yüküyle de birisi tanı almamış üç tane özel gereksinimli öğrenciye yeterli olamayacağını düşünmektedir. Bu nedenle Ahmet'i sınıfına kabul etme konusunda gönülsüz olduğunu Müdür beye telefonda söylemiş̧ir. Ancak Ahmet'in hali hazırdaki sınıf öğretmeninin yetersiz kaldığını da bilmektedir. Eğer Ahmet mevcut sınıfında kalırsa, arkadaşlarıyla arasındaki fark daha da açılacaktır. Konuşmadan sonra Müdür Ali Bey konuyu daha doğru biçimde ele almak ve doğru bir karar vermek için ne yapması gerektiğini düşünmektedir.

\section{Birinci Basamak: Konuya İlişkin Bilgilerin Toparlanması}

Bu basamakta "Konuya ilişkin olgular nelerdir? Olaya kimler dâhildir? Kişilerin söylediklerinden başka neler öğrenebilirim? Konuya ilişkin resmi bir mevzuat var mı? Bağlamsal faktörler nelerdir” şeklindeki sorulara 
yanıtlar aranmaktadır. Bu sayede etik ikilemin açık ve net biçimde anlaşılması amaçlanmaktadır. Eksik kalan ya da yanlış anlaşılan durumların olup olmadığının başlangıçta kontrol edilmesi, değerlendirme sürecinin sağlam bir temel üzerinde devam etmesini sağlayacaktır. Konuya ilişkin farklı kaynaklardan toparlanan bilgiler şunlardır:

a. ̇l merkezindeki okulda yaklaşık 500 öğrenci eğitim görmektedir. İkinci sınıflardaki dört şubede toplam 120 öğrenci kayıtlıdır. Bunlardan ikisi zihin yetersizliği tanısı almış kaynaştırma öğrencisidir.

b. Okulda hali hazırda bir özel eğitim öğretmeni yoktur.

c. Okulda destek eğitim odası yoktur.

d. Okuldaki sınıf öğretmenleri, özel gereksinimli öğrenciler konusunda herhangi resmi bir eğitim almamıştır.

e. Öğrenci Ahmet'in, birinci sınıftaki akademik kazanımları çok düşük seviyededir.

f. Öğrenci velisi Zeki Bey, geçen yıldan beri çocuğu Ahmet’in eğitsel tanılama için değerlendirilmesini istememektedir.

g. Ayşe öğretmenin sınıfında hali hazırda iki kaynaştırma öğrencisi vardır. Özel eğitim hizmetleri yönetmeliğine göre, bir sınıfta aynı tanı grubundan en fazla iki kaynaştırma öğrencisi eğitim görebilmektedir. Fakat Ahmet'in eğitsel tanısı olmadığı için, ikinci sınıfta Ayşe öğretmenin şubesinde eğitim görmesinde resmi bir engel yoktur.

Bu basamakta, ilk olarak problemin ortaya çıktığı ortama ilişkin nicel veriler sıralanmıştır. Bunların yanı sıra, okulda yaşanan sorunla ilişkili olabilecek durumlar (okulda kaynaştırma uygulamaları için herhangi bir çalışma yapılmamış olması) ve problemin belirmesine neden olan kişilere ilişkin bilgiler de toparlanmıştır.

\section{İkinci Basamak: Konuyla İlişsili Kişilerin ve Bakış Açılarının Belirlenmesi}

Bu basamakta yanıt aranan sorular ile olaydaki kişilerin bakış açıları, davranışlarını etkileyen faktörler anlaşılmaya çalışılmaktadır. Bu basamakta amaç, durumu etkileyen ya da durumdan etkilenen beşeri unsurları belirlemektir. "Durum ile alakası olan kişiler kimlerdir? Bu kişilerin duruma ilişkin bakış açıları nasıldır? Bu kişilerin davranışları ya da tutumları üzerinde etkili olabilecek sosyal ve kültürel etmenler neler olabilir? Durumla ilişkili olabilecek herkesin fikri alındı mı?" biçiminde sorular araştırılabilir. Olaydaki aktörlere ilişkin değerlendirmeler aşağıdaki gibidir:

a. Öğrenci velisi Zeki Bey, çocuğunun iyi bir eğitim almasını istemektedir. Ancak herhangi bir tanı almasını istememektedir. Tanı alması durumunda, diğer öğrencilerin ve velilerinin, çocuğunu dışlayacağını düşünmektedir.

b. Okul Müdürü Ali Bey, arkadaşı olan öğrenci velisini, çocuğu için eğitsel tanı almaya ikna edememiştir. $\mathrm{Bu}$ nedenle, ilk başta öğrenci velisinin isteği doğrultusunda durumu çözmeyi düşünmüştür. Sonrasında bu problemi daha uygun biçimde ele almak için çalışmaya başlamıştır.

c. Ahmet'in birinci sınıftaki öğretmeni, öğrencinin kendi şubesinde sınıftan geride kaldığını ve öğrenciye yardımcı olamadığını söylemektedir. Öğrenciye öğretim sunmak için gerekli olan bilgi ve beceriden yoksun olduğunu, şimdiye kadar okul idaresinden bu konuda bir destek görmediğini belirtmektedir. Bu nedenle de öğrencinin eğitsel tanı almasının, mümkünse de özel eğitim okulunda ya da özel eğitim sınıfında eğitim görmesinin daha iyi olacağını söylemektedir.

d. Ayşe öğretmen; Ahmet'in durumuna üzüldüğünü ancak öğrencinin kendi şubesine gelmesi durumunda, artacak yükü nedeniyle öğrencilerine faydalı olamayacağı kaygısını yaşadığını söylemektedir.

e. Ayşe öğretmen, geçen yılki veli toplantılarında bazı velilerin kaynaştırma öğrencilerine ilişkin çekincelerini dile getirdikleri söylemektedir. Kendisi bu ön yargıları yıkmak için yoğun çaba göstermiş ve kısmen başarılı da olmuştur.

f. Diğer ikinci sınıf şubelerinin öğretmenleri, özel eğitim konusunda bilgili olmadıklarını, mevcut iş yükü nedeniyle zaten zorlandıklarını, bir de özel gereksinimli öğrenciler ile başa çıkamayacaklarını belirtmektedirler.

g. Okuldaki rehberlik öğretmeni, mevcut iş yükünden dolayı, özel gereksinimli öğrenciler için yeterince aktif olamadığını ifade etmektedir. Özel eğitim uygulamaları konusunda da kendisini yetersiz hissettiğini belirtmektedir.

h. Bazı öğrenci velilerinin, kaynaştırma öğrencilerinin kendi çocuklarını olumsuz etkileyeceğine ilişkin kaygıları olduğu öğretmenlerce bilinmektedir.

İkinci basamakta, aktörler kendi bakış açılarına göre durumu yorumlamaktadırlar. Sorunun çok katmanlı yapısı da artık belirmeye başlamaktadır. Öğretmenlerin ve velilerin olumsuz tutumları, okulda kaynaştırma 
uygulamalarının şimdiye kadar sahiplenmemiş olması ile ilişkili görülmektedir. $\mathrm{Bu}$ tutumlar, yeni problemlerin ortaya çıkmasına neden olmaktadır.

\section{Üçüncü Basamak: Etik İhlalin/İkilemin Belirlenmesi ve Tanımlanması}

Bu basamakta "Etik ihlallerin doğası tam doğru olarak anlaşıldı mı? Hangi etik kurallar ve değerler ile ihtilafa düşülmüş?” şeklindeki sorulara cevap aranmaktadır. Karşılaşılan durumlar, bazen birbiri ile ilişkili birden fazla etik ihlal içerebilir. Bunların her birinin ve aralarındaki ilişkilerin belirlenmesi gerekmektedir. Bu aşamada etik ihlallerin kaynağına ilişkin faktörler de belirgin hale gelmektedir. Bu basamakta, örnek olayda yer alan kişilerin yaşadığı etik ikilemler tanımlanmaktadır.

1. Geçen sene yaşanan etik ihlaller şunlardır:

a. Ahmet'in birinci sınıftaki öğretmeni, öğrencisi için herhangi bir sınıf içi uyarlama gerçekleştirmemiştir. Öğrencinin tanılanmamış olmasını bahane olarak görmüştür. Sonuçta öğrencinin akademik kazanımları düşük seviyede kalmıştır.

b. Geçen seneki okul müdürü, öğrencinin eğitsel tanı sürecini başlatmamıştır.

2. Bu sene ortaya çıkan etik ikilemler ise şunlardır:

a. Okul müdürü, herkes için en iyisinin ne olacağına karar vermeye çalışmaktadır. Öğrenci, okuldaki diğer öğrenciler, öğrencinin velisi, Öğretmen Ayşe Hanım ve diğer öğretmenler verilecek kararlardan etkilenecektir.

b. Ayşe öğretmen, Öğrenci Ahmet'i sınıfına almaya razı gelmez ise öğrenci kendi sınıfında düşük performans göstermeye devam edecektir. Öğrenciyi kabul ederse de sınıfındaki eğitim- öğretim faaliyetlerinin genel kalitesi düşecektir.

Yukarıdaki tanımlamalara göre, geçen yıl ortaya çıkan etik ihlaller, şu an yaşanan etik ikilemlere zemin hazırlamıştır. Geçmişteki durumların değiştirilmesi mümkün olmasa da etik ikilemlere zemin hazırlayan unsurların belirlenmiş olması, etik ikilemin doğasının anlaşılmasını kolaylaştırmaktadır. Bu bilgiler sonraki basamaklarda kullanılmaktadır.

\section{Dördüncü Basamak: Karara İlişkin Seçeneklerin Belirlenmesi}

“İkilemin çözümü için seçenekler neler olabilir? Bütün seçenekler belirlendi mi?” şeklindeki sorularla etik ikilemde karar vermeyi sağlayacak seçenekler dördüncü basamakta belirlenmektedir. Bu basamakta, olaydaki aktörlere ilişkin bütün seçeneklerin ortaya konması tavsiye edilmektedir. Bu sayede daha önce fark edilmemiş yeni bakış açıları ortaya çıkabilir. Aşağıda Ali Bey’in belirlediği seçenekler yer almaktadır.

1. Öğrenci Ahmet için eğitsel değerlendirme istenmeyecek ve öğrenci eğitimine olduğu gibi devam edecektir.

a. Öğrenci Ahmet, Ayşe öğretmenin şubesinde ikinci sınıfa başlayacaktır.

b. Öğrenci Ahmet, mevcut şubesinde eğitim görmeye devam edecektir.

c. Öğrenci Ahmet, aynı okulda başka bir şubede ikinci sınıfa başlayacaktır.

2. Öğrenci velisi ikna edilecek ve Öğrenci Ahmet için eğitsel değerlendirme istenecektir. Eğitsel tanılama sonrasinda;

a. Öğrenci Ahmet, Ayşe öğretmenin şubesinde ikinci sınıfa başlayacaktır. Bunun yapılabilmesi için de iki kaynaştırma öğrencisinden bir tanesi başka bir sınıfa kaydırılacaktır.

b. Öğrenci Ahmet, mevcut şubesinde eğitim görmeye devam edecektir.

c. Öğrenci Ahmet, başka bir şubede ikinci sınıfa başlayacaktır.

3. Öğrenci velisinin ikna edilmesine çalışılmayacak, öğrenci için eğitsel değerlendirme sürecini okul idaresi takip edecektir. Öğrencinin şubesi daha sonra belirlenecektir.

4. Öğrenci velisi, Ahmet'in okulda kalmasına yönelik ikna edilmesine çalışılmayacak, Öğrenci Ahmet'in başka bir okula transferi sağlanacaktır.

\section{Beşinci Basamak: Seçeneklerin Etik Analizinin Yapılması}

Beşinci basamak, önceki basamakta oluşturulmuş olan seçeneklerin farklı yöntemler ile değerlendirilmesini içermektedir. Warnick ve Silverman'ın (2011) kullanılmasını önerdikleri yöntemlerden bir tanesi sonuçlara dayalı yaklaşımdır; burada seçenekler olası sonuçlarına göre değerlendirilmektedir. Kullanılabilecek bir diğer yöntem ise seçeneklerin etik analize tabi tutulmasıdır. Bu yöntemde seçenekler; mesleki etik ilkeler ya da etik teoriler ile bir arada ele alınmaktadır. Duruma bağlı olarak; bu yöntemlerden herhangi bir tanesi ya da ikisi beraberce kullanılabilmektedir. Sonuçlara dayalı yaklaşıma göre, dördüncü basamaktaki seçenekler için aşağıdaki senaryolar oluşturulabilir. Bunlar içerisinde; 1.a., 1.b. ve 1.c. senaryolarında, öğrencinin 
eğitsel değerlendirmeden geçmediği durumda olabilecekler; 2.a., 2.b. ve 2.c. seçeneklerinde ise eğitsel değerlendirmenin yapıldığı ve sonrasında öğrencinin tanı aldığı bir durumda olabilecekler incelenmektedir.

1.a. Öğrenci Ahmet, Ayşe öğretmenin şubesinde ikinci sınıfa başlayacaktır. Ayşe öğretmen, sınıfındaki bütün öğrencilere yararlı olmak istemektedir. Bu nedenle elinden geldiği kadarıyla sınıfındaki bütün öğrencileri desteklemeye çalışacaktır. İkinci sınıf itibarıyla artan akademik gereksinimler ve Ahmet'in şubeye katılması nedeniyle, her bir öğrencisine ayıracağı vakit daha sınırlı olacaktır. Bu nedenle sınıfindaki eğitimin etkililiği ve verimliliği azalabilir.

1.b. Öğrenci Ahmet kendi şubesinde eğitimine devam edecektir. Olay bu biçimde gündeme gelmiş olduğu için, öğretmenin Ahmet'in eğitim faaliyetlerine katılımı için daha fazla çaba göstermesi beklenebilir. Ancak gerek öğretmenin bilgisinin sınırlı olması gerekse Ahmet'in birinci sınıftan kalan eksiklikleri nedeniyle, öğrencinin başarılı olması çok da ihtimal dâhilinde gözükmemektedir.

1.c. Öğrenci Ahmet'in kaydı okuldaki diğer ikinci sınıflardan birine de yapılabilir. Bu şubelerin öğretmenleri de zihinsel yetersizliği olan öğrenciler konusunda kendilerini yetersiz hissetmekte, bu nedenle de öğrenciyi kabul etmekte isteksiz davranmaktadırlar. Bu seçenekte de öğrencinin başarılı olması düşük bir ihtimaldir.

2.a. Öğrenci Ahmet eğitsel değerlendirme sonrasında, kaynaştırma öğrencisi olarak Ayşe öğretmenin şubesine yerleştirildiğinde, kendisi için BEP hazırlanacaktır. Bu sayede öğrencinin gereksinimlerinin karşılanmasına yönelik resmi bir belge de oluşturulmuş olacaktır. Ahmet'e yer açılması için başka şubeye geçecek öğrenci konusunda ise Ayşe Öğretmen böyle bir duruma razı olmayacağını söylemektedir, bu nedenle kendisinin ve öğrenci velisinin bu konuda ikna edilmesi gerekecektir. Bu seçenekte Ahmet'in daha iyi bir eğitim alması muhtemeldir. Diğer şubeye geçecek olan kaynaştırma öğrencisi ise diğer öğretmenlerin mevcut tutumları ve yeterlikleri nedeniyle bu dönem büyük ihtimalle sınırlı düzeyde kazanımlar elde edecektir.

2.b. Bu seçenekte, öğrencinin eğitsel değerlendirme sonrasında, kendi sınıfında devam ettiği durum ele alınmaktadır. Bu seçenekte Öğrenci Ahmet kaynaştırma öğrencisi olursa kendisi için yine BEP hazırlanacaktır. Bu belge sayesinde eğitim-öğretim faaliyetleri en azından "kâğıt üzerinde" güvence altına alınmış olacaktır. Ancak bunun dışında, yukarıdaki 1.b. seçeneğinde tartışılan gerekçeler nedeniyle öğrencinin kazanımlarının yine düşük seviyede kalması beklenmektedir.

2.c. Öğrencinin tanı aldıktan sonra, kaydının başka bir şubeye alınması durumunda, öğrenci için BEP hazırlanmış olması dışında 1.c. seçeneğinde tartışılan gerekçeler nedeniyle öğrenci kazanımlarının düşük seviyede kalması beklenmektedir.

3. Bu seçenekte, ebeveyn ile iş birliği içerisinde olunmadığı için, sürecin idaresi konusunda güçlükler yaşanması olasıdır.

4. Öğrencinin başka bir okula transfer edilmesi seçeneğinde, okul, öğrenci ve velisi arasındaki ilişki sonlanmış olacaktır. Öğrenci velisi mevcut tutumunu muhtemelen sürdüreceği için, Ahmet'in durumu başka bir okulda benzer bir probleme yol açabilir.

Görüldüğü üzere bu seçeneklerin her biri, olaydaki en az bir aktörü olumsuz etkilemektedir, dolayısıyla hiçbir seçenek tam olarak tatmin edici değildir.

\section{Altıncı Basamak: Durumun Öğretmen Gözüyle Değerlendirilmesi}

Warnick ve Silverman (2011) bu basamakta, öğretmenliğin gerekliliklerine ilişkin bir hatırlatma yapmaktadır. Bu basamakta, "Öğretmenlerin; öğrencilere, alana ya da meslek örgütüne sorumlukları nelerdir?" sorusuna cevap aranmaktadır. Müdür Ali Bey, idareci olarak okuldaki bütün öğrencilerin üstün yararına olan bir karar vermesi gerektiğini düşünmektedir. Bunun yanı sıra, vereceği karar öğretmenlik mesleğinin ve yöneticisi olduğu okulun itibarını olumsuz etkilememelidir. Ancak oluşturulan seçeneklerin hiçbiri mevcut haliyle bunları sağlamamaktadır.

\section{Yedinci Basamak: İkileme İlişkin Görüş Alışverişi ve Araştırma Yapılmasıı}

$\mathrm{Bu}$ basamakta konuya ilişkin yardımcı olabilecek diğer kaynaklara başvurulması önerilmektedir. Bu kaynaklar; bu konularda deneyimli uzmanlar ya da kitaplar ve makaleler olabilir. Bunun yanı sıra etik değerlendirmelerin tek bir kişinin sorumluluğuna ve bakış açısına bırakılmaması gerektiği de vurgulanmaktadır. Değerlendirme yapan kişiler de bu örnekte olduğu üzere, olayın bir parçası olabilirler ya da meseleyi kendi bakış 
açılarına göre değerlendirerek, süreçte eksik noktalar bırakabilirler. Etik ikilemlerin mümkün olduğunca, önceden oluşturulmuş bir etik kurul tarafindan, grup tartışması biçiminde ele alınması daha uygun görülmektedir. Bu tip uygulamalar, kurum içerisindeki etik kültürünü de canlı tutacaktır (Snarney \& Samuelson, 2008).

Bu basamakta Okul Müdürü Ali Bey, lisans eğitimi gördüğü bölümdeki bir öğretim üyesinden konuya ilişkin destek almıştır. Hocasının önerisiyle de durumu, bir müdür yardımcısı ve Milli Eğitim Müdürlüğünde görevli bir özel eğitim öğretmeni ile beraberce değerlendirmeye karar vermiştir. Öğretim üyesi ayrıca Ali Bey’e oluşturduğu seçenekleri başka bir biçimde analiz etmesini sağlayacak bir model önermiş̧tir. Ali Bey, oluşturduğu seçenekleri bir de bu model ile analiz etmeye karar vermiş̧ir.

\section{Beşinci Basamağa Geri Dönüş̧: Etik Analiz Modelinin Uygulanması}

Sonuçlara dayalı yaklaşım bu olayda verimli olmadığı için, Ali Bey, beşinci basamağa geri dönmüştür. Dördüncü basamakta oluşturduğu seçenekleri değerlendirmek için, Starratt'nn (1994) temellendirdiği, Stefkovich ve O’Brien (2004) ile Furman'ın (2004) eklemeler yaptığı etik modeli kullanmaya karar vermiştir. Bu model okul ortamındaki davranışları, etik nitelikleri bakımından değerlendirmek için oluşturulmuştur. Model, en başından okul ortamındaki unsurlar ve süreçler gözetilerek oluşturulduğu için, eğitim-öğretim faaliyetlerinin etik doğasına tam olarak odaklanabilmektedir. Modelde değerlendirilmeler şu beş kavram üzerinden yapılmaktadır: Kritik etiği, adalet etiği, özen etiği, profesyonellik etiği ve okul ortamı etiği. Bu kavramlar, aşağıda örnek olay çerçevesinde özetlenmekte ve Ali Bey’in gözünden örneklendirilmektedir.

1. Kritik etiği: $\mathrm{Bu}$ kavram, okul ortamında statükoya hizmet eden unsurların değerlendirilmesini içermektedir. $\mathrm{Bu}$ unsurlar bir bakıma herkesin alışageldiği ancak aslında işlevsel olmayan değerlendirmeler, kurallar, tutumlar ya da ilişkiler olabilir. "Yaşanan etik dışı davranışa zemin hazırlayan koşullar ve durumlar neler olabilir?" gibi sorularla mevcut düzenden kaynaklanan aksaklıkların anlaşılması ve karar verirken bunların gözetilmesi amaçlanmaktadır. Durumun kritiği yapıldığında etik ihlallere zemin hazırlayan iki unsur dikkat çekmektedir:

a. Okulda kaynaştırma uygulamasına ilişkin bir kurum kültürü oluşmamıştır.

b. Öğretmenlerin ve velilerin bir kısmı kaynaştırma öğrencilerine yönelik olumsuz tutumlar içerisindedirler. Bu tutumlar normalleşmiştir.

2. Adalet etiği: Eşit ve adil olanı bulmak için yapılan sorgulamalar bu başlık altında ele alınmaktadır. Buna göre, herkesin yararına olan ama aynı zamanda bireysel hakları da gözeten adaletli bir çözüm aranmalıdır. Seçeneklerin adalet bakımından değerlendirilmesi, bütün bireylerin adalet duygusunu tatmin edebilmelidir. Adalet etiğine göre durum değerlendirildiğinde, aşağıdaki sonuçlara varılmaktadır:

a. Okuldaki özel gereksinimli öğrenciler, durumlarından dolayı firsat eşitliğinden mahrum kalmamalıdır.

b. Kaynaştırma uygulamalarında okuldaki bütün personel eşit sorumluluk taşımalıdır.

3. Özen etiği: Bu kavram, öğretmenlik mesleğindeki insancıl bakış açısını vurgulamaktadır. Öğretmenler, idareciler, diğer çalışanlar, öğrenciler ve aileler arasında saygıya dayalı bir anlayış gözetilmelidir. Bir öğretmenin karşısındaki kişiye; sosyo-ekonomik düzeyi, maddi durumu, inancı veya özel gereksiniminden bağımsız olarak saygıyla yaklaşması ve sadece insan olduğu için davranışlarında "özenli” olması bu kavramla vurgulanmaktadır. Bunlara ek olarak öğretmenlerin çalışma arkadaşları ile uyumları artıkça, velilere ve öğrencilere gösterdikleri özen de bundan olumlu etkilenecektir. Bu basamakta yapılan değerlendirmeler, verilen kararlarda bu özenin sergilenip sergilenmediğine ilişkindir:

a. Okuldaki bütün öğrencilere ve velilere değer verilmelidir.

b. Okul personelinin kendi arasındaki iletişim ve iş birliği geliştirilmelidir.

c. Okul ve aileler arasındaki iletişim ve iş birliği geliştirilmelidir.

4. Profesyonellik etiği: Bu kavram, mevcut modele Stefkovich ve O’Brien (2004) tarafindan eklenmiştir. Profesyonelliğe ilişkin sorgulamalar öncelikle eğitimcilerin görev tanımlarına uygun biçimde hareket edip etmediklerine ilişkindir. Buna ek olarak, Stefkovich ve O'Brien (2004) profesyonelliği öğretmenlerin mesleklerini icra ederken "öğrencinin üstün yararını" gözetip gözetmediklerine ilişkin olarak de ele almaktadırlar. Bu göre öğretmenlerin temel vazifesi öğrencilerin üstün yararını gözetmektir, bu ilke öğretmenlik ve ilişkili branşlar için birincil vazgeçilmezdir. Öğretmenler de kararlarında bu ilkeyi gözetmelidirler.

a. Verilecek kararlarda öncelik öğrencinin üstün yararı olmalıdır. "Öğrenci” ile kastedilen sadece Ahmet değil, okuldaki bütün öğrencilerdir.

b. Öğretmenler, özel eğitim hizmetlerine ilişkin yasal mevzuatın gerekliliklerine göre hareket etmelidirler. 
5. Okul ortamı etiği: Bu kavramı modele ekleyen Furman (2004), önceki kavramlar ve okul ortamındaki etik arasında karşılıklı bir etkileşim olduğunu söylemektedir. Okul ortamı etiği, mevcut bir yapıdan ziyade devam eden bir süreci tanımlamaktadır. Bu süreç okuldaki bütün beşeri unsurlar arasında karşılıklı bir anlayışın ve paylaşımın olmasını, ortak bir kurumsal amaç oluşturulmasını kapsamaktadır. Buna göre:

a. Herkesin fayda göreceği ve olumlu bir okul iklimi yaratmaya katkı sağlayacak bir karar alınmalıdır.

$\mathrm{Bu}$ değerlendirmeler sonucunda, Ali Bey, dördüncü basamakta oluşturulan 2.b. seçeneğinin (Öğrenci velisi ikna edilecek ve Öğrenci Ahmet için eğitsel değerlendirme istenecektir. Sonrasında Öğrenci Ahmet, mevcut şubesinde eğitim görmeye devam edecektir.) yukarıda ele alınan kavramlar gözetilerek şu biçimde oluşturulabileceğini görmüş̧ür:

1. Okuldaki bütün personel için kaynaştırma/bütünleştirme uygulamalarına yönelik bilgilendirme ve tutum değiştirme çalışmalarının başlatılması (Kritik etiği a, b).

2. Okuldaki bütün öğrenciler ve veliler için kaynaştırmaya hazırlık etkinliklerinin planlanması ve uygulanması (Kritik etiği a, b).

3. Okuldaki görev dağılımının ve sorumluluk alanlarının yeniden oluşturulması (Kritik etiği a, Adalet etiği b, Özen etiği b)

4. Öğrenci için eğitsel tanılama sürecinin başlatılması (Profesyonellik etiği a, b)

5. Okulda destek eğitim sınıflarının açılması için işlemlerin başlatılması (Adalet etiği a)

6. Kaynaştırma sınıflarında görev yapacak ücretli öğretmenlerin istihdamının sağlanması (Adalet etiği a)

7. Okulun, Milli Eğitim Müdürlüğünde görevli özel eğitim öğretmenleri ile ve araç-gereçlerle desteklenmesi için taleplerin oluşturulması (Adalet etiği a)

\section{Sekizinci Basamak: Bir Karar Verilmesi, Kararın Diğer Seçenekler Arasından Neden Seçildiğinin Gerekçelendirilmesi}

$\mathrm{Bu}$ basamakta, seçenekler arasından "en uygun" olanının seçilmesi amaçlanmaktadır. Warnick ve Silverman (2011), bu basamakta yapılması gerekenlere dair net bir yöntem sunmamışlardır, bu nedenle bu uygulamayı bir "yöntem" olarak değil de "çerçeve" olarak isimlendirmektedirler. Bu basamak itibari ile artık olaydaki aktörler ve olgular belirlenmiştir. Problemin çözümüne ilişkin seçenekler de olası senaryolar ve etik değerlendirmeler ile ele alınmıştır. Bu örnek olayda etik kavramlar gözetilerek oluşturulan 2.b. seçeneği tercih edilmiştir. Sonuçlara dayalı yaklaşım okuldaki mevcut durumu kollayan seçenekler ürettiği için verimli olmamıştır. Öğretmenlik mesleğine ilişkin etik kavramları kullanan diğer yöntem ise zahmetli, ancak öğrenciler başta olmak üzere herkesin yararına olacak bir çözüm sunmaktadır. Oluşturulan basamakların her biri okul ortamı etiği ile de uyum içerisindedir.

\section{Dokuzuncu Basamak: Karar Verildikten Sonraki Sürecin Nasıl Takip Edileceğinin Belirlenmesi}

Bu basamak için tekrar Furman'ın (2004) tanımladığı okul ortamı etiğine geri dönülebilir. Yapılması gerekenler okuldaki etik uygulamaları artıran, etik olmayanları azaltan uygulamalardır. Bu olay özelinde ise yeni bir anlayış ile oluşturulan kaynaştırma uygulamalarının, bütün paydaşları kapsayacak biçimde denetlenmesi gerekmektedir.

Verilen bu örnekte okul müdürünün ortaya çıkan etik ikilemi ele alırken yapıcı bir yaklaşım sergilediği söylenebilir. Örnek olayda, bütün olayların müsebbibi olan fena bir karakter yoktur. Gerçek hayattaki problemlerde ya da ikilemlerde de suçlu bir kişi aramak her zaman verimli olmayacaktır. Warnick ve Silverman'ın (2011) uygulama çerçevesi, öğretmen etiği kavramları (Furman, 2004; Starratt, 1994; Stefkovich \& O’Brien 2004) ile beraber kullanıldığında özel eğitimcilerin karşılaştığı durumları çözüme kavuşturmada faydalı olabilir.

\section{Sonuç ve Öneriler}

Bu çalışmada meslek etiğine ilişkin kuramsal bilgiler ve öğretmen adaylarının, öğretmenlerin ve idarecilerin kullanabilecekleri bir etik değerlendirme çerçevesi sunulmuştur. Özel gereksinimli bireylere sunulan hizmetlerde etik ihlallerin ve bunların olumsuz etkisinin azaltılması, doğru kararların oranının artırılması mümkündür. Bunu sağlamak için öğretmen adaylarına eğitimleri sırasında gerekli bilgi ve becerilerin kazandırılması, öğretmen yeterliliklerinin hizmet içi eğitimler yoluyla desteklenmesi, etik ve uygulama ilkelerinin kurumlarca da gözetilmesi gibi uygulamalara öncelik verilmesi gerekmektedir. Özel eğitim alanında ya da özel gereksinimli öğrencilerle çalışanlar, etik değerlendirmeler konusunda bilgi ve deneyim sahibi olduklarında, önlerine çıkan etik ikilemler karşısında daha doğru kararlar alabilirler. Türkiye'de özel eğitimdeki etik ikilemler ve ihlaller çok farklı biçimlerde ortaya çıkabilmektedir (Akçamete vd., 2016). Bu nedenle yabancı bir çalışmadan 
uyarlanan etik değerlendirme çerçevesinin, ülkemizdeki bütün koşulları gözeten bir çözüm sunması mümkün değildir. $\mathrm{Bu}$ bağlamda, ülkemizde bu konudaki alanyazını genişletecek çalışmalara gereksinim olduğu söylenebilir. Bunun için öncelikle, özel eğitim alanında yaşanan etik ikilemlerin/ihlallerin ve bunlara neden olan unsurların belirlenmesine yönelik çalışmaların artııılması önerilmektedir. Sonrasında etik ikilemlere ve ihlallere yönelik çözümler sunacak etik değerlendirme çerçeveleri oluşturulabilir. Oluşturulan bu çerçevelerin alandan gelen geri bildirimler ile daha rafine bir hale getirilmesi ve etkililiklerinin değerlendirilmesi de gerekmektedir. $\mathrm{Bu}$ çalışmalar orta ve uzun vadede ülkemizdeki özel gereksinimli bireylere sunulan hizmetlerin etik niteliğini artıracaktır.

\section{Teşekkür}

Katkılarından dolayı Ethem Özdemir'e minnettarım. 


\section{Kaynaklar}

Akçamete, G., Kayhan, N., İşcen-Karasu, F., Sardoohan-Yıldırım, A. E., \& Şen, M. (2016). Professional ethical principles for special education teachers. SDU International Journal of Educational Studies, 3(1), 27-44. https://dergipark.org.tr/tr/pub/sduijes/issue/20865/223879

Apgar, K. P. (2018). Teacher ethics code violations that result in licensure or certification sanctions [Unpublished doctoral thesis]. University of Portland.

Audi, R. (1999). The Cambridge dictionary of philosophy. Cambridge University Press.

Bascia, N. (2015). Perspectives on teacher unions: History, discourse, and renewal. In N. Bascia (Ed.), Teacher unions in public education (pp. 1-8). Palgrave Macmillan.

Benjamin, M., \& Curtis, J. (1981). Ethics in nursing. The Journal of Ambulatory Care Management, 4(3), 86. https://journals.1ww.com/ambulatorycaremanagement/Citation/1981/08000/Ethics_in_Nursing.11

Benninga, J. S. (2013). Resolving ethical issues at school. Issues in Teacher Education, 22(1), 77-88. https://files.eric.ed.gov/fulltext/EJ1013919.pdf

Bon, S. C., \& Bigbee, A. J. (2011). Special education leadership: Integrating professional and personal codes of ethics to serve the best interests of the child. Journal of School Leadership, 21(3), 324-359. https://doi.org/10.1177/105268461102100302

Brodhead, M. T., \& Higbee, T. S. (2012). Teaching and maintaining ethical behavior in a professional organization. Behavior Analysis in Practice, 5(2), 82-88. https://doi.org/10.1007/BF03391827

Bullough Jr, R. V. (2011). Ethical and moral matters in teaching and teacher education. Teaching and Teacher Education, 27(1), 21-28. https://doi.org/10.1016/j.tate.2010.09.007

Colnerud, G. (1997). Ethical conflicts in teaching. Teaching and Teacher Education, 13(6), 627-635. https://doi.org/10.1016/S0742-051X(97)80005-4

Collins. (n.d.). Collins dictionary. Retrieved May $1, \quad$ 2020, from https://www.collinsdictionary.com/us/dictionary/english/law-abiding

Cook, B. G., \& Schirmer, B. R. (2003). What is special about special education? Overview and analysis. The Journal of Special Education, 37(3), 200-205. https://doi.org/10.1177/00224669030370031001

Council for Exceptional Children (2015). Ethical principles and professional practice standards for special educators. https://www.cec.sped.org/Standards/Ethical-Principles-and-Practice-Standards

Downie, R. S. (1980). Ethics, morals and moral philosophy. Journal of Medical Ethics, 6(1), 33-34. http://dx.doi.org/10.1136/jme.6.1.33

Durkheim, E. (1957). Professional ethics and civic morals. Routledge.

Ehrich, L. C., Kimber, M., Millwater, J., \& Cranston, N. (2011). Ethical dilemmas: A model to understand teacher practice. Teachers and Teaching: Theory and Practice, 17(2), 173-185. https://doi.org/10.1080/13540602.2011.539794

Fenstermacher, G. D. (1990). Some moral considerations on teaching as a profession. In J. I. Goodlad, R. Soder, \& K. A. Sirotnik (Eds.), The moral dimensions of teaching (pp. 130-151). Jossey-Bass.

Friedman, H. H. (2017). Cognitive biases that interfere with critical thinking and scientific reasoning: A course module. https://papers.ssrn.com/sol3/papers.cfm?abstract id=2958800

Frolov, I. (Ed.). (1997). Felsefe sözlüğ̈̈ [Dictionary of philosophy]. (A. Çalışlar, Çev.). Cem Yayınevi.

Furman, G. C. (2004). The ethic of community. Journal of Educational Administration, 42(2), $215-235$. https://doi.org/10.1108/09578230410525612

Gert, B., \& Gert, J. (2017). The definition of morality. In E. N. Zalta (Ed.), The Stanford encyclopedia of philosophy (Fall 2017 Ed.). https://plato.stanford.edu/archives/fall2017/entries/morality-definition

Hodgkinson, C. (1991). Educational leadership: The moral art. Suny Press. 
Howe, K. R., \& Miramontes, O. B. (1991). A framework for ethical deliberation in special education. The Journal of Special Education, 25(1), 7-25. https://doi.org/10.1177/002246699102500102

İşgüden, B., \& Çabuk, A. (2006). Meslek etiği ve meslek etiğinin meslek yaşamı üzerindeki etkileri [Professional ethics and effects of professional ethics on business life]. Balıkesir Üniversitesi Sosyal Bilimler Enstitüsü Dergisi, 9(16), 59-86. https://dergipark.org.tr/en/download/article-file/863784

Justia US Law. (n.d.) Mills v. Board of Education of District of Columbia, 348 F. Supp. 866 (D.D.C. 1972). https://law.justia.com/cases/federal/district-courts/FSupp/348/866/2010674/

Kamu Görevlileri Etik Davranış İlkeleri ile Başvuru Usul ve Esasları Hakkında Yönetmelik [Regulation on Ethical Behavior Principles of Public Officials and Application Procedures and Basis]. (2005) T.C. Resmi Gazete, (25785), 13 Nisan 2005.

Kamu Görevlileri Etik Kurulu [Ethics Committee of Public Officials]. (2012). Kamu görevlileri etik rehberi [Ethical guide for public officals]. http://etik.gov.tr/etik_rehberi.pdf

Keser, S., Kocabaş, I., \& Yirci, R. (2013). The ethical perceptions of elementary school teachers in the triple perspective classification of ethics. Turkish Online Journal of Qualitative Inquiry, 4(3), 1-16. https://doi.org/10.17569/tojqi.39773

Kuluçlu, E. (2008). Türk hukuk sisteminde normlar hiyerarşisi ve Sayıştay denetimine etkileri [Hierarchy of norms and its effect on Court of Accounts audit Turkish law system]. Saylştay Dergisi, 71, 3-22. http://www.acarindex.com/dosyalar/makale/acarindex-1423911557.pdf

Lord Nelson, L. G., Summers, J. A., \& Turnbull, A. P. (2004). Boundaries in family-professional relationships: Implications for special education. Remedial and Special Education, 25(3), 153-165. https://doi.org/10.1177/07419325040250030301

Milli Eğitim Bakanlığı [Ministry of National Education]. (2015). Eğitimciler için mesleki etik ilkeler genelgesi [Professional principles circular for educators]. http://personel.meb.gov.tr/meb_iys_dosyalar/2016_06/02032141_mesleki_etik_ilkeler.pdf

Milli Eğitim Bakanlığı [Ministry of National Education]. (2008). Özel ĕgitim öğretmeni özel alan yeterlikleri [Special education teacher specific field competencies].

O’Donohue, W., \& Ferguson, K. E. (2011). Behavior analysis and ethics. In W. W. Fisher, C. C. Piazza, \& H. S. Roane (Eds.), Handbook of applied behavior analysis (pp. 489-497). The Guilford Press.

Osgood, R. L. (2005). The history of inclusion in United States. Gallaudet University Press.

Özel Eğitim Hakkında Kanun Hükmünde Kararname [Decree Law on Special Education]. (1997). T. C. Resmi Gazete, (23011), 6 Haziran 1997, 857-866.

Özel Eğitim Hizmetleri Yönetmeliği [Special Education Services Regulation]. (2018). T. C. Resmi Gazete, (30471), 7 Temmuz 2018, 22-77.

Paul, J. L., French, P., \& Cranston-Gingras, A. (2002). Ethics and special education. Focus on Exceptional Children, 34(1), 1-16. https://core.ac.uk/download/pdf/235895864.pdf

Prentice, R. (2014). Teaching behavioral ethics. Journal of Legal Studies Education, 31(2), 325-365. https://doi.org/10.1111/jlse.12018

Starratt, R. J. (1994). Building an ethical school: A practical response to the moral crisis in schools. Routledge.

Stefkovich, J. A., \& O’Brien, G. M. (2004). Best interests of the student: An ethical model. Journal of Educational Administration, 42(2), 197-214. https://doi.org/10.1108/09578230410525603

Stephens, T. M. (1985). Personal behavior and professional ethics: Implications for special educators. Journal of Learning Disabilities, 18(4), 187-192. https://doi.org/10.1177/002221948501800402

Stockall, N., \& Dennis, L. R. (2015). Seven basic steps to solving ethical dilemmas in special education: A decision-making framework. Education and Treatment of Children, 38(3), 329-344. https://doi.org/10.1353/etc.2015.0015 
The National Education Association. (1929). Code of ethics of the National Education Association of the United States. https://www.jstor.org/stable/20257817?seq=1

The National Education Association. (2010). Code of ethics. http://www.nea.org/home/30442.htm

Türk Dil Kurumu [Turkish Language Association]. (t.y.). Güncel Türkçe sözlük [Contemporary Turkish dictionary]. Retrieved March 16, 2020, from https://sozluk.gov.tr

Uzun, S., \& Yolsal, Ü. H. (2008). Felsefe sözlüğü [Dictionary of philosophy]. Bilim ve Sanat.

Vuran, S. (Ed.). (2020). Özel ĕgitim öğretmenleri için belirlenmiş etik ilkeler kılavuzu [Ethical principles guide for special education teachers]. Vize Akademik.

Warnick, B. R., \& Silverman, S. K. (2011). A framework for professional ethics courses in teacher education. Journal of Teacher Education, 62(3), 273-285. https://doi.org/10.1177/0022487110398002

Weaver, K. (2007). Ethical sensitivity: State of knowledge and needs for further research. Nursing Ethics, 14(2), 141-155. https://doi.org/10.1177/0969733007073694

Weiss, C. L. A., \& Mettrick, J. E. (2010) Individuals with disabilities education act (IDEA). In C. S. ClaussEhlers (Ed.). Encyclopedia of cross-cultural school psychology. Springer. https://doi.org/10.1007/9780-387-71799-9_212

Winzer, M. A. (1993). The history of special education: From isolation to integration. Gallaudet University Press. 


\section{Ankara University Faculty of Educational Sciences Journal of Special Education}

2022, 23(1), 219-241
REVIEW

Recieved Date: 18.06 .20

Accepted Date: 27.01.21

OnlineFirst: 21.02 .21

\title{
Professional Ethics and Ethical Evaluations in Special Education
}

\author{
Onur Özdemir iD 1
}

\begin{abstract}
Introduction: Professional ethics can be defined as standards that determine, dictate and observe the behaviors that employees should display or avoid while performing their profession. These standards are defined by established ethical and practical principles. Therefore, ethical and practical principles are indispensable elements of professional ethics. Ethical evaluation is another element that may be necessary to ensure standards regarding professional ethics. It is a systematic problem-solving process that leads to appropriate decisions in ethical violations or dilemmas. It can be said that special education is more vulnerable toward ethical violations. For this reason, educators must have knowledge and skills about ethics and ethical evaluations. Despite these necessities, it is seen that studies relating to special education professional ethics in Turkey have begun to emerge recently and these studies are limited in number. Therefore, the aim of this study is to share information on ethics along with theoretical and practical information related to ethical principles and evaluations within the scope of special education.

Conclusion and Recommendations: Ethical evaluation framework presented in the study provides an exemplary content that may be useful considering Turkey's conditions and assess their effectiveness. Along with studies on other elements that make up professional ethics, these would contribute to well-being of both service receivers and providers.
\end{abstract}

Keywords: Special education, professional ethics, ethical principles, ethical dilemmas, ethical evaluation process.

To cite: Özdemir, O. (2022). Professional ethics and ethical evaluations in special education. Ankara University Faculty of Educational Sciences Journal of Special Education, 23(1), 219-241. https://doi.org/10.21565/ozelegitimdergisi.754783

\footnotetext{
${ }^{1}$ Lecturer, Ph. D., Marmara University, E-mail: onur.ozdemir@ marmara.edu.tr, https://orcid.org/0000-0002-7242-6946
} 


\section{Introduction}

Special education involves efforts to improve the quality of life of students and their relatives, in a sense, that other fields have difficulty to "reach". But still, the field of special education is open to problems. Some of these problems are related to unethical behaviors. Surprisingly, research and discussion on the ethical issues have just recently started in special education in Turkey. This text will hopefully contribute to the understanding of professional ethics in special education. For this purpose, the concept of ethics will be discussed in terms of professional ethics. Afterwards, the legal and organizational ethics regulations in Turkey and United States of America will be evaluated. A practical framework that can result in ethically appropriate decisions will be described in the context of a case that can be encountered in Turkey.

\section{Ethics and Professional Ethics}

The basis of the common use of the ethics is philosophy. Ethics or moral philosophy deals with right and wrong behavior and includes different subfields such as meta-ethics, descriptive ethics, normative ethics and applied ethics. In daily life, ethics is more commonly used in the context of normative and applied ethics. Applied ethics includes the evaluation of debates on normative ethics in a particular situation (O'Donohue \& Ferguson, 2011; Uzun \& Yolsal, 2008). For instance, this situation may refer to work life. Therefore, professional ethics is defined as "the principles and standards that evaluate professional behavior, and specify appropriate and inappropriate behavior" (İşüden \& Çabuk, 2006).

In this context, professional ethics moves away from the concept of morality. By definition, morality is a social structure governing behavior that affects other people toward good (Audi, 1999). Although moral system imposes what is right or wrong, in moral decisions an individual still has her/his own opinion. Professional ethics, on the other hand, reduces the impact of personal factors on the decision thanks to the external standards. Another distinction between ethics and morality arises from division of labor in modern societies (Durkheim, 1957).

Another social structure that defines and imposes appropriate behavior is law. In some cases however, laws may involve some unethical practices. Therefore, individuals may act ethically by objecting to these laws. Generally speaking, the main difference between professional ethics and laws is the scope of legal regulations. By nature, laws and related low-level legislation (e.g. regulations) describe responsibilities, rights, and practices. However, they do not usually consider the context (Bon \& Bigbee, 2011). Therefore, it is necessary to apply professional ethical principles and conduct ethical evaluations in order to address these "gray areas" which refer to gaps in the legislation (Ethics Committee of Public Officials, 2012).

The concept of professional ethics has been emphasized in recent years. The number of institutions that regulate and observe ethical practices in the public and private sectors has increased in Turkey since 2000. For example, the Ethics Committee of Public Officials was established in 2004 to identify and observe the ethical behaviors that public officials must comply with. Ethical rules that regulate the behavior of employees and have certain authority have become an important element of professionalism in Turkey. In recent years, more practices and discussions regarding ethical behaviors in the field of special education have also been observed. In 2016, the "ethics in special education" course was added to the undergraduate curriculum of the special education. Also, a committee including academics, specialists and non-governmental organization representatives identified ethical principles for special education teachers.

\section{Ethics in Education and Special Education}

According to Hodgkinson (1991), educational activities essentially consist of ethical and moral activities based on fundamental values. Therefore, how can teachers be encouraged to behave in an ethically appropriate way? One of the answers to this question may be the establishment of professional ethical rules and their implementation in a way that includes regulations. Thanks to ethical principles, teachers and other specialists can gain insight into the consequences of their behavior, the objectives and limits of their expertise, and appropriate behavior (Apgar, 2018). In some countries, it is seen that the ethical standards that educators must comply have a history of nearly a century. For example, the National Education Association, one of the professional organizations in the USA published the codes of ethics that members must follow in 1929. In this document, a total of 21 ethical codes were listed under the headings including (a) ethical rules regarding students and community, (b) ethical rules about the teaching profession, and (c) ethical rules for the members of the profession. The first document that gave instructions directly on the ethical principles to the educators in Turkey was published by the Ministry of National Education (MoNE) in 2015. 
Despite this humanitarian understanding and continuing developments until today, ethical violations are still encountered in the field of special education. Ethical violations can occur in many different ways. Akçamete et al.'s (2016) study which was conducted in Turkey identified various unethical behaviors of special education teachers. "Individuals who did not receive vocational training in the field of special education and those who had insufficient vocational education, focusing only on financial benefits, not providing equal opportunities to students, not considering the expectations and needs of the family, giving false information to the family, exploiting the naiveness and feelings of the family, not respecting the family" are some examples. Unethical behaviors may emerge in many different ways than the examples that attract attention in the media, such as "violence against students" or "parents' offensive behaviors to an inclusive student". Professional ethical codes in the field of special education aim to prevent the emergence of these behaviors. One of these is the Ethical Principles and Professional Practice Standards published by the Council for Exceptional Children (CEC) in 2015 in the USA. Ethical standards for special educators have been established recently in Turkey (Vuran, 2020). The Special Education Competencies published by MoNE, the most appropriate resource referring to appropriate behaviors for special educators, was also repealed in 2018. Regarding official legislation, the fourth article in the Special Education Act published in 1997 included "fundamental principles of special education". These principles point to what needs to be done in special education. Therefore, it can be considered as the most appropriate legal resource related to ethics in special education in Turkey.

\section{Ethical Evaluations on Special Education}

Ethical principles may not always be sufficient to demonstrate correct behavior. In some cases, the situations that are not included in professional ethical principles may also be encountered. For this reason, it is stated that teachers should have an ethical understanding of why a behavior is right or wrong (Warnick \& Silverman, 2011). In this way, teachers will be able to evaluate ethical behaviors more efficiently. These evaluations are concerned with which behaviors are appropriate in certain situations and which are not, and aim to answer the question: "What should be done in the face of a particular situation, considering everything?" (Benjamin \& Curtis, 1981). Ethical dilemmas may occur when there are multiple behavioral options that may have different results and where these options do not have a clear advantage over each other (Paul, et al., 2002). In the presence of many different variables, it may not always be easy to achieve the right outcome in ethical dilemmas. Individual characteristics, the presence or absence of professional ethical principles, corporate culture, public interest or indifference, economic context, legal legislation, relevant policies, social or cultural elements, socialadministrative pressures may have positive or negative effects on the decisions to be made (Ehrich et al., 2011). In the literature, there are many decision-making strategies that yield ethical evaluations in a structured framework (e.g. Benninga, 2013; Stockall \& Dennis, 2015; Warnick \& Silverman, 2011). These strategies handle ethical dilemmas as a problem that needs to be solved and apply problem-solving steps (Warnick \& Silverman, 2011). In the following, a framework for ethical evaluation (Warnick \& Silverman, 2011) will be given with an imaginary case that takes place in Turkey. The framework consists of nine successive steps which are presented in Table 1 .

\section{Table 1}

\section{Steps for Ethical Evaluation}

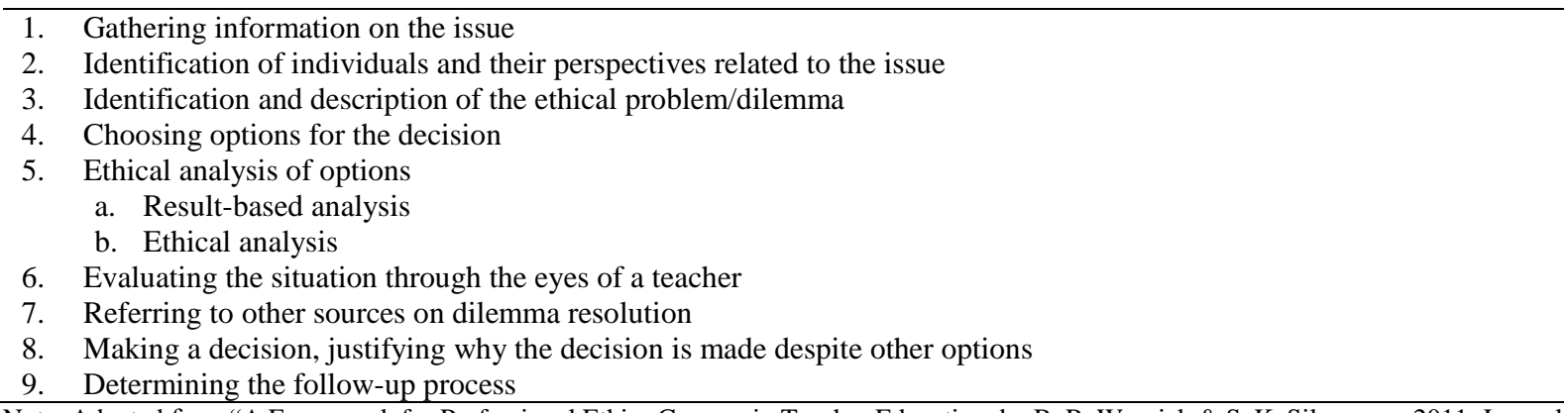
Note: Adapted from "A Framework for Professional Ethics Courses in Teacher Education, by B. R. Warnick \& S. K. Silverman, 2011, Journal of Teacher Education, 62(3), p. 278.” Copyright 2011 by Sage Publishing.

Warnick and Silverman (2011) formed each of these steps based on ethical decision-making literature. An important advantage of this approach is that it helps teachers adopt proactive precautions correctly before ethical dilemmas arise (Stockall \& Dennis, 2015). In educational institutions, an ethical culture will be created if training and follow-up procedures on these are offered to the staff members (Brodhead \& Higbee 2012). The steps in the framework are explained below in accordance with the case study presented. Also in accordance with the 
framework of Warnick and Silverman (2011), the steps Mr. Skinner should follow to solve the dilemma are explained below.

\section{Case Study}

Mrs. Krabappel who is an elementary school teacher feels anxious 15 days before the schools open. The principal of the school asks the Mrs. Krabappel whether she would accept a second-grade student with special needs to her class. The father of the student, Mr. Flanders, wishes that his child enrolls in Mrs. Krabappel's class. In the first year, the student whose is name is Nelson demonstrates poor performance in Turkish and Mathematics Noticing the situation, his teacher in the first grade informs the guidance service and the parents of the student, but Mr. Flanders who does not want his child to receive the diagnosis, does not take any steps. When the classroom teacher does not see any progress following a few attempts, the teacher leaves the child on his own in the classroom. Thus, a year of education passes with a limited gain.

At the beginning of the new school year, Mr. Flanders asks for help when Principal Mr. Skinner, who is a former friend, becomes the head of the school. He asks Mr. Skinner to transfer his child to the class of Mrs. Krabappel whom he hears well about her practices before. In this way, he hopes that his child will catch up with other students without any diagnosis. Although Mr. Skinner says that it would be better for the student to have a diagnosis, he can not persuade Mr. Flanders who thinks that other children and parents approach negatively mainstreaming students. Mr. Flanders also implies that, if his request is not fulfilled, he would transfer his son to another school. Mr. Skinner who does not want to upset his friend says that he would talk to Mrs. Krabappel.

There are currently two students with special education needs in Mrs. Krabappel's class who will be teaching second year students this year. Because of the fact that she does not receive any meaningful support from the school since last year, Mrs. Krabappel is exhausted. Considering this workload, she is thinking that she may not have the energy for three students with special needs. Therefore, she tells Mr. Skinner that she is reluctant to accept Nelson in her class. However, she also knows that Nelson's current classroom teacher is inadequate. If Nelson remains in his current class, the gap between him and his friends will become even more evident. Following the conversation, Mr. Skinner is thinking about what he should do to handle the issue and make the right decision.

\section{Step One: Gathering Information on the Issue}

In this step, answers to these and similar questions are sought: "Who are involved in the situation? What else can I learn from what people say? Is there an official legislation on the subject? What are the contextual factors?"

a. Approximately 500 students are enrolled in the school. A total of 120 second-grade students receive education at four different classes. Two of them have intellectual disability.

b. There is no special education teacher at the school at present.

c. The school does not have a resource room.

d. The teachers at the school have not received any formal training on students with special needs.

e. Nelson's academic achievement in the first year is very limited.

f. Mr. Flanders does not accept that his child will be evaluated for diagnosis since last year.

g. Mrs. Krabappel already has two students with special education needs in her class. According to the special education services regulation, a maximum of two students with the same disability can receive education in the class. Since Nelson does not have a diagnosis, there is no official obstacle for him to enroll in this class in the second year.

\section{Step Two: Identification of Individuals and Their Perspectives Related to the Issue}

The perspectives of the people and the factors affecting their behavior are addressed through the following questions: "Who are the people involved in this problem? What are their perspectives?"

a. Mr. Flanders wants his child to receive a good education. However, he does not want any diagnosis. He thinks that if his son receives any diagnosis, other students and their parents will exclude his child.

b. Nelson's teacher in the first year says that the student is behind his peers in her class and she can not help the student as she doesn't have any knowledge on special education.

c. Mrs. Krabappel says that she is not happy about Nelson's condition. However, she is concerned that if the student comes to her class, she will not be beneficial to her students due to an increase in the workload.

d. The teachers of other second-grade classes state that they do not have any knowledge about special education, they already have difficulties due to the current workload. Thus they cannot cope with students with special needs. 


\section{Step Three: Identification and Description of the Ethical Problem/Dilemma}

The following questions are asked in this step: "Is the nature of the ethical problem fully understood? Which ethical rules and values are in conflict?"

1. Ethical violations in the past year are as follows:

a. Nelson's teacher in the first grade does not make any in-class adaptations for her student.

b. School principal in charge last year does not start the diagnostic process for the student.

2. Currently, there are two different ethical dilemmas through the eyes of two actors

a. The new principal is trying to decide what is best for everyone.

b. If Mrs. Krabappel does not agree to include Nelson into her class, the student will continue to perform poorly in his current class. If she accepts the student, the general quality of the educational activities in her class will decrease.

\section{Step Four: Choosing Options for the Decision}

The following questions are asked in this step: "What can be the options for the solution of dilemma? Have all the options been identified?"

1. Educational evaluation for Nelson will not be requested and his education will continue as it is.

a. Nelson will start the second year at Mrs. Krabappel's class.

b. Nelson will continue to study in his current classroom.

c. Nelson will start the second year in another class.

2. The student's parent will be persuaded. An assessment session will be required for Nelson.

a. Nelson will start the second year at Mrs. Krabappel's class. To do this, one of the two students with special education needs will be transferred to another class.

b. Nelson will continue to study at his current class.

c. Nelson will start the second year in another class.

3. The student's parent will not be persuaded. The school administration will follow the assessment process for the student. The student's class will be determined later.

4. The student's parent will not be persuaded. Nelson will be transferred to another school.

\section{Step Five: Ethical Analysis of Options}

This step includes evaluating options with various methods. One of the methods Warnick and Silverman (2011) address is the deterministic approach in which the options are evaluated according to their possible results. Another method is to conduct an ethical analysis for each option. In this method, options are addressed by professional ethical principles or ethical theories (if available). Depending on the situation, either one or both of these methods can be used together. According to the results-based approach, the following scenarios can be suggested in the fourth step: In scenarios 1.a., 1.b. and 1.c., whether the student is subject to educational evaluation is examined. In 2.a., 2.b. and 2.c. options, the consequences that might arise when the student receives the diagnosis following the evaluation are examined.

\section{Step Six: Evaluating the Situation through the Eyes of a Teacher}

At this step, Warnick and Silverman (2011) give a reminder regarding the requirements of teaching in that they ask the following question: "What are the responsibilities of teachers to students, education field and profession?" Decision-makers should consider these aspects of teaching profession while applying the framework.

\section{Step Seven: Referring to Other Sources on Dilemma Resolution}

In this step, other sources (books, professors, etc.) are referred for assistance. Therefore, Mr. Skinner decides to ask for support from a faculty member in the special education department and decides to apply an ethical decision model in order to analyze the options.

\section{Back to Step Five: An Ethical Analysis Model}

The ethical model, based on Starratt (1994) with additions from Stefkovich and O'Brien (2004) and Furman (2004), will be used to create and evaluate the content of the 2.b. option. In accordance with this model, the ethical quality of behaviors at schools is evaluated through the concepts including the ethic of critique, ethic of justice, ethic of care, ethic of the profession, ethic of community. 
1. Ethic of critique: This concept includes the evaluation of the elements that serve the status quo in the school environment. These elements may be used by everyone. However, they may be actually dysfunctional evaluations, rules, attitudes, or relationships between people.

a. There is no institutional culture for mainstreaming in the school.

b. Some of the teachers and parents have negative attitudes towards mainstreaming students. These attitudes have become norm for the school.

2. Ethic of justice: Inquiries to find the equal and fair are undertaken under this heading.

a. Students with special needs at school should not be deprived of equal opportunities due to their condition.

b. All staff in the school should have equal responsibility in mainstreaming practices.

3. Ethic of care: This concept emphasizes the humanitarian perspective in ethical decisions. It focuses on a respectful understanding and behaviors among teachers, administrators, other employees, students and families.

a. All students and parents in the school should be valued.

b. Communication and cooperation among staff members should be improved.

c. Communication and cooperation between school and families should be improved.

4. Ethic of the profession: Stefkovich and O'Brien (2004) added this concept. The inquiries about professional ethics are about whether the educators regard the "best interests of the student" in their decisions.

a. The priority of the student should be first in the decisions to be made.

b. Employees must act according to the requirements of legal regulations for special education services.

5. Ethic of community: This process involves a mutual understanding among all the human elements in the school. It also ensures that people gather around a common institutional purpose.

a. A decision should be taken that will benefit everyone and contribute to creating a positive school climate.

As a result of these evaluations, 2.b. was modified with following steps in order to solve the ethical dilemma:

1. Initiation of meetings for education and attitude change on mainstreaming for all staff members (Critic ethics $a, b)$.

2. Planning and implementation of preparatory activities on mainstreaming for all students and parents in the school (Critic ethics a, b).

3. Re-establishing the distribution of duties and responsibilities in the school (Critic ethics a, justice ethics b, care ethics b).

4. Starting the educational evaluation process for the student (Professional ethics a, b).

5. Initiation of procedures to open resource room at school (Justice ethics a).

6. Ensuring the employment of assistant teachers who will work in mainstreaming classes (Justice ethics a).

7. Making requests towards provincial directorate of education regarding the availability special education teacher and materials support (Justice ethics a).

\section{Step Eight: Making a Decision, Justifying Why the Decision was Chosen among Other Options}

In this step, the aim is to choose the "most suitable" option. Warnick and Silverman (2011) does not provide a clear method of what to do at this step. Therefore, they call this practice a "framework" rather than a "method". In this case, the option 2.b. is chosen. The deterministic approach is not productive as it offers options that favors the current status quo at school. The other method uses ethical concepts related to the teaching profession and provides a solution which requires effort that will benefit everyone in the medium term. Each of the steps is also in harmony with the ethics of the school environment.

\section{Step Nine: Determining for the Follow-up Process}

For this step, the community ethics defined by Furman (2004) will be fruitful. The practices that increase ethical behaviors at school and reduce unethical ones should be prioritized.

\section{Conclusion and Recommendations}

In this article, the concept of professional ethics and an ethical evaluation framework that can be used by prospective teachers, teachers and administrators is presented. It is possible to reduce the intensity and impact of ethical violations and increase the ratio of right decisions in services delivered to individuals with special needs. In order to achieve this, teacher candidates should be equipped with the necessary knowledge and skills during 
their education, teacher competencies need to be supported through in-service training and ethical principles should be watched by institutions. Ethical dilemmas and violations can occur in many different ways (Akçamete et al., 2018). So, it is not possible for the ethical evaluation framework mentioned in this article to offer a solution that takes all elements into consideration. It is recommended to increase the number of studies to identify ethical dilemmas or problems in the field of special education and the factors that cause them. In this way, ethical evaluation frameworks can provide better solutions to these ethical dilemmas and problems. These frameworks should also be refined with the feedback from the field. Their effectiveness should be evaluated. These studies will increase the ethical quality of special education activities in Turkey in the long term.

\section{Acknowledgment}

I'm grateful to Ethem Özdemir for his contributions. 